\title{
The August 2010 earthquake swarm at North FAMOUS-FAMOUS segments, Mid-Atlantic Ridge: geophysical evidence of dike intrusion
}

\author{
Marion Giusti, ${ }^{1}$ Julie Perrot, ${ }^{1}$ Robert P. Dziak, ${ }^{2}$ Alexey Sukhovich ${ }^{1}$ and Marcia Maia ${ }^{1}$ \\ ${ }^{1}$ CNRS-Université de Bretagne Occidentale, Laboratoire Géosciences Océan, Institut Universitaire Européen de la Mer, Place Nicolas Copernic, Plouzane \\ 29280, France. E-mail: marion.giusti@univ-brest.fr \\ ${ }^{2}$ NOAA, Pacific Marine Environmental Laboratory Newport, OR 97365, USA
}

Accepted 2018 June 19. Received 2018 May 24; in original form 2017 October 20

\begin{abstract}
S UMMAR Y
In August 2010 a network of five hydrophones moored south of the Azores recorded an unusual earthquake swarm at the North FAMOUS and FAMOUS segments of the Mid-Atlantic Ridge (MAR). This earthquake swarm was comprised of $>700$ events, was focused off-axis and extended spatially $>70 \mathrm{~km}$ across the Non-Transform Offset (NTO) separating the two segments. Acoustic waves of broad-band spectrum $(1-80 \mathrm{~Hz})$ were generated by the onset of the swarm for $>20 \mathrm{hr}$. A total of 30 earthquakes from the swarm were detected teleseismically, four had Centroid Moment Tensor (CMT) solutions derived. The CMT solutions indicated three normal faulting events and one non-double-couple event. The spatio-temporal distribution of the seismicity and broad-band energy show evidence of two magma dike intrusions at the North FAMOUS segment, with one intrusion crossing the NTO also evidenced by fine resolution of low Mantle Bouguer Anomaly value. This may be the first intrusion event detected along the northern MAR since the Lucky Strike segment intrusion observed in 2001.
\end{abstract}

Key words: Atlantic Ocean; Acoustic properties; Mid-ocean ridge processes; Submarine tectonics and volcanism.

\section{INTRODUCTION}

Mid-Ocean Ridge (MOR) volcanic activity is a fundamental process for creation of new ocean crust, yet the dynamics of magma emplacement along the slow-spreading $\left(\sim 25 \mathrm{~mm} \mathrm{yr}^{-1}\right)$ northern Mid-Atlantic Ridge (MAR) is largely unknown. In general the MAR is characterized by a $1.5-3 \mathrm{~km}$ deep, $15-30 \mathrm{~km}$ wide axial rift valley with both transform fault and non-transform offsets. The rift valley commonly contains an axial ridge that is considered to be the predominant site of volcanic activity (Ballard \& van Andel 1977). Based on the sizes of the volcanic ridges, large volumes of lava must be erupted on the valley floor (Smith \& Cann 1993). Currently, however, we do not know how frequently magmatic events occur, whether there are spatial patterns in these events, or how they vary through time.

MOR volcanic activity has long been known to produce earthquake swarms of mostly low-magnitude earthquakes that are typically below the detection threshold of land-based seismic networks $\left(m_{\mathrm{b}}<4.5\right.$; Bergman \& Solomon 1990). The most effective method to observe deep-ocean MOR volcanism in real time is by the remote detection of seismicity associated with the intrusion of magma into brittle ocean crust. However, the relatively high detection thresholds of land-based seismic networks $(M>4)$ for the majority of the global MOR system (Bohnenstiehl et al. 2002), often result in an incomplete picture of the volcanic episodes or a failure to detect the episode altogether. During the last two decades, the value of hydroacoustic studies in monitoring MOR seismicity has been demonstrated through use of arrays of moored Autonomous Underwater Hydrophones (AUHs; e.g. Fox et al. 2001). Focused arrays of hydrophones were first used to monitor seismic activity along the slow-spreading MAR in 1999 (Smith et al. 2002; Simao et al. 2010; Goslin et al. 2012), with the goal of developing a better understanding of the tectono-magmatic mechanisms driving seafloor spreading at the MAR. More recently, the HYDROMOMAR project was initiated in 2010-2011 (HM10-11; Perrot 2010, 2011) to complement these previous arrays by deploying five hydrophones on the flanks of the MAR south of the Azores archipelago between $30^{\circ} \mathrm{N}$ and $40^{\circ} \mathrm{N}$ (-upper inset). All of the HYDROMOMAR AUHs are moored in the axis of the Sound Fixing and Ranging (SOFAR) channel (at the depth of $\sim 1000 \mathrm{~m}$, Table 1). At the ocean crust/sea water interface, seismic waves are converted to low-frequency acoustic waves $(<40 \mathrm{~Hz})$, called Tertiary or $T$ waves. These acoustic waves can propagate in the water-column over very large distances $(\geq 1000 \mathrm{~km})$ once they become trapped in the SOFAR channel.

In August 2010, a remarkable swarm of more than 700 earthquakes was recorded at the FAMOUS and North FAMOUS segments of the MAR, $350 \mathrm{~km}$ south of the Azores (Fig. 1). This area is well studied as it was the focus site of the French American Mid-Ocean Undersea Study (FAMOUS) project from 1971 to 1974 
Table 1. Location of the hydrophones, bathymetric depth and mean depth of the SOFAR channel axis in August 2010 (data from Generalized Digital Environmental Model Variable Resolution, Teague et al. 1990). All the AUHs are moored at $1000 \mathrm{~m}$ from the ocean surface during the HM10-11 cruise.

\begin{tabular}{lccc}
\hline AUH & Location $\left({ }^{\circ} \mathrm{N} /{ }^{\circ} \mathrm{W}\right)$ & Bathymetry $(\mathrm{m})$ & SOFAR axis $(\mathrm{m})$ \\
\hline LS & $37.080 / 31.920$ & 2170 & 1500 \\
M2 & $39.421 / 34.106$ & 3670 & 1300 \\
M6 & $37.593 / 38.360$ & 3870 & 1400 \\
M7 & $32.453 / 32.455$ & 3520 & 1600 \\
M8 & $36.250 / 29.331$ & 3470 & 1600 \\
\hline
\end{tabular}

(Heirtzler \& Van Andel 1997). The recent seismic activity at the FAMOUS site was exceptional in its intensity and duration as compared to previous swarms detected hydroacoustically at the MAR. We suggest that the spatio-temporal distribution of the earthquake activity derived from the combined observation of the teleseismic and hydroacoustic events, as well as the presence of the long-duration, high-energy, broad-band acoustic energy at the swarm onset, are consistent with a magmatic intrusion event along the FAMOUS and North FAMOUS segments. Moreover, a high-resolution gravity model of the Non-Transform Offset's (NTO) density structure between these two segments indicates the presence of a low-density area within the earthquake cluster.

\section{GEOLOGICAL SETTING}

Part of the MAR is located in a ridge-hot spot interaction context with the proximity of the Azores hot spot. A long-wavelength influence is inferred from the along axis variation in axial depth (shallower topography and thicker crust than expected) and gravity (more negative Mantle Bouguer Anomaly (MBA) centred on the Azores Plateau; Thibaud et al. 1998; Goslin et al. 1999; Maia et al. 2007). Higher mantle temperature beneath the ridge axis and abundant melt production led to excess crust forming large oceanic plateaus (Princess Alice Bank and Jussieu Plateau; Cannat et al. 1999; Gente et al. 2003). The plume's influence is observed along the axis until the northern limit $43.67^{\circ} \mathrm{N}$ (Goslin et al. 1999; Maia et al. 2007) whereas its southern limit is still debated. Thibaud et al. (1998) suggest a plume influence until $26.5^{\circ} \mathrm{N}$. However, variations in geology and ridge morphology in the segments south of $37.2^{\circ} \mathrm{N}$ discontinuity are noticed and characterized by well-developed axial valleys and outcrops of serpentinized peridotites (Escartin et al. 2001). These variations are attributed to a decrease in the thermal regime and/or in magma supply (Detrick et al. 1995). Segments north of $37.2^{\circ} \mathrm{N}$ (Lucky Strike, Menez Gwen segments) are known to be more robust with higher amounts of neovolcanism (Parson et al. 2000). This could place the southern limit of the Azores influence around this latitude pointing out a north/south asymmetry of the plume influence extended mainly southwards (Thibaud et al. 1998; Goslin et al. 1999; Yang et al. 2006; Maia et al. 2007).

The August 2010 earthquake swarm is spatially distributed on the historic North FAMOUS (20 km long) and FAMOUS (42 km long) segments of the MAR (Parson et al. 2000, Fig. 1). The FAMOUS site is renowned as the site of the first manned submersible investigation of the MOR, performed by the French submersible 'Archimede' in 1973 (Ballard et al. 1975). The objective of these in situ studies has been to define the tectonic and volcanic processes, and geologic structures, associated with genesis of new oceanic crust (e.g. Choukroune et al. 1978; Goud \& Karson 1985; Macdonald 1977; Gracia et al. 2000; Parson et al. 2000).
Thibaud et al. (1998) described the FAMOUS segment as an 'intermediate segment' meaning that it has a highly variable axial morphology with a moderate, along-axis Mantle Bouguer Anomaly ( $\triangle \mathrm{MBA})$. The North FAMOUS segment is 'colder', as exemplified by its wide and deep axial valley and smaller $\triangle \mathrm{MBA}$ (Thibaud et al. 1998) as well as a well-developed axial volcanic ridge (Ballard et al. 1975). In contrast the FAMOUS segment does not have a clearly defined axial volcanic ridge (Ballard et al. 1975), instead the axial valley floor is composed of fresh pillow mounds and a zone of faulted volcanic constructs along the east valley (Parson et al. 2000). At the northern end of this segment, the ridge-axis faults tend to curve into the NTO that separates it from the North FAMOUS (Parson et al. 2000). The ridge outer walls are asymmetrical about the valley axis and the spreading rate is highly asymmetrical, $7 \mathrm{~mm}$ $\mathrm{yr}^{-1}$ to the west and $13.4 \mathrm{~mm} \mathrm{yr}^{-1}$ to the east (Macdonald et al. 1977). Moreover, Gale et al. (2013) suggest that the FAMOUS segment lacks a centrally located, large magma chamber where volcanism is instead supplied by multiple small magma bodies along the length of the segments. The presence of several small magma bodies results in the ability of melts to deliver highly diverse magmas over short spatio-temporal scales.

The east-west NTO that separates the North FAMOUS and FAMOUS segments is a relatively young NTO (1.6 Ma, Parson et al. 2000 ), offsets the rift valleys of the segments by $\sim 20 \mathrm{~km}$, and is $\sim 9 \mathrm{~km}$ wide and $2.9 \mathrm{~km}$ deep (Detrick et al. 1973). The transition between the NTO and the North FAMOUS segment is not clearly defined mainly because the northern and southern walls are structurally complex with $\mathrm{E}-\mathrm{W}$ and $\mathrm{N}-\mathrm{S}$ trending scarps (Detrick et al. 1973). The valley of the NTO is comprised of shallow faulted blocks extending from the segment's flanks, trending parallel to the ridge segments and cut by a WSW/ENE-trending strike-slip fault (Gracia et al. 2000). The small active zone of strike-slip faulting is 300-1000 m wide (Choukroune et al. 1978) and has been shown, using sonobuoys (Reid \& Macdonald 1973) to be active at the microseismic level with roughly 10 events per day. Massive dolerite dikes have been found cutting the northern NTO block, whereas fossil Fe-Mn hydrothermal deposits have been noted on the southern section of the NTO (Choukroune et al. 1978). 10 submersible dives, covering a section of the north-central part of the NTO valley, discovered dike intrusions and pillow lavas and allowed structural interpretation of the median part of the NTO (Figs 2 and 6 from Choukroune et al. 1978).

\section{GEOPHYSICAL DATA AND METHODS}

\subsection{The hydroacoustic experiment HM10-11}

The HYDROMOMAR array was first deployed in 2010-2011 and is comprised of five hydrophones moorings located on the flanks of the MAR south of the Azores between $30^{\circ} \mathrm{N}$ and $40^{\circ} \mathrm{N}$ (- upper inset). The hydrophones continuously record acoustic pressure variation at a sampling rate of $240 \mathrm{~Hz}$ (1-120 Hz bandpass). The hydrophone array data is routinely analysed for $T$-wave earthquake arrivals by visual scans of the spectrograms. The analysis software SEAS (Fox et al. 2001) is then used to derive the $T$-waves source locations by selecting the arrival time of the maximum of the $T$-wave energy. Generally, the location of $T$-wave source corresponds to the earthquake epicentre but can differ since $T$ waves are generated by scattering from a rough seafloor and thus the acoustic source area on the seafloor can cover an area of several $\mathrm{km}^{2}$ (e.g. de Groot-Hedlin 


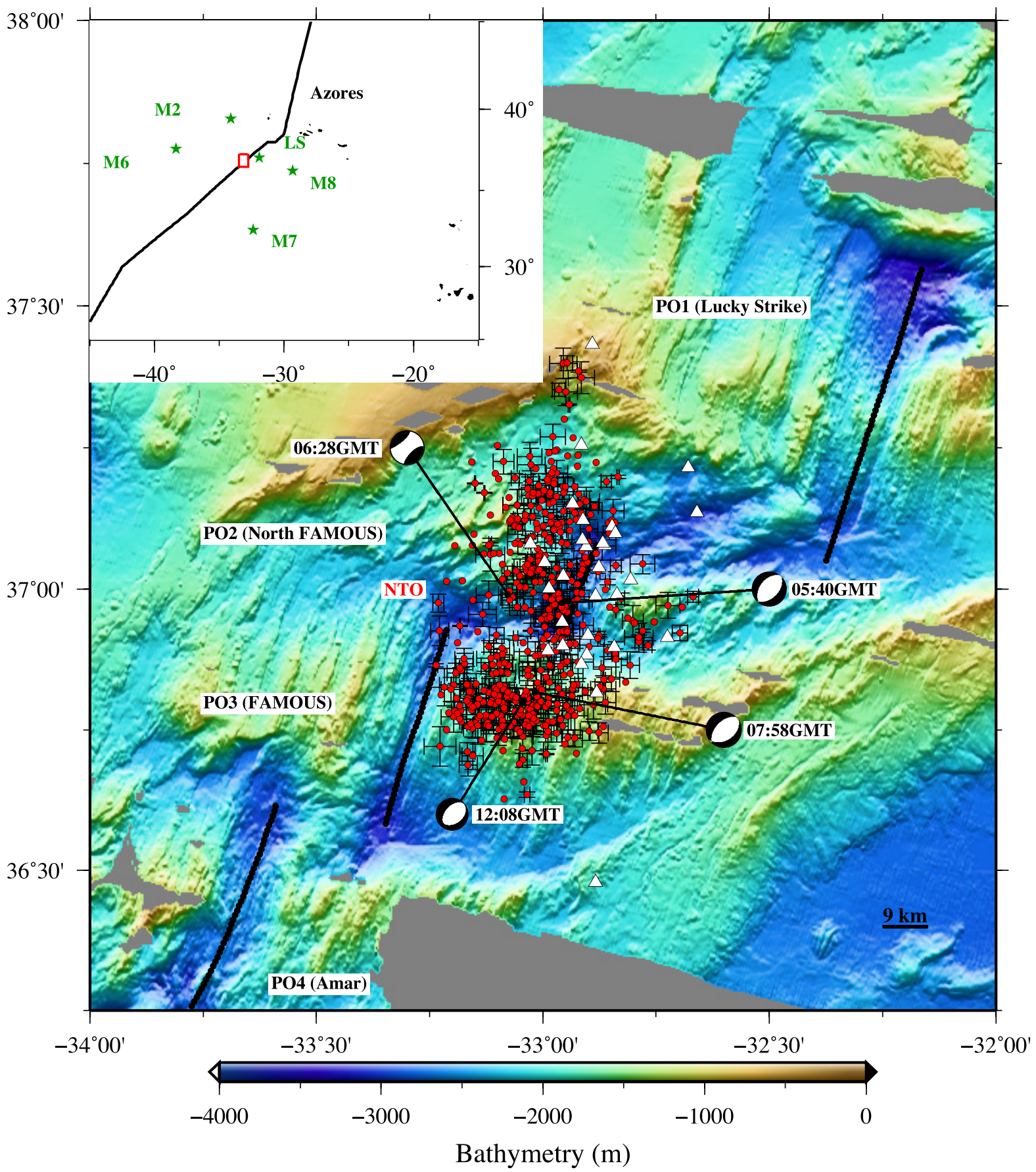

Figure 1. Upper inset shows the location of the HYDROBS-MOMAR 2010-2011 hydrophones (green stars) relative to the FAMOUS area (red rectangle). Bathymetric map (gridded bathymetry from multibeam bathymetric survey [Detrick et al. 1995; Cannat et al. 1999], pixel-resolution of $300 \mathrm{~m}$ ) of the FAMOUS area segments (black axis) of the Mid-Atlantic Ridge. Hydroacoustic locations (red dots) of the August 2010 swarm (Single Link Cluster analysis) associated to their error bars showing the $(2 \sigma)$ location uncertainties (only for events $\geq 4$ AUHS). Teleseismic epicentres (white triangles) from the ISC catalog and hydroacoustic epicentres of the four main shocks associated to their full moment tensor solution GCMT (Global Centroid Moment Tensor, Ekström et al. 2012).

\& Orcutt 2001). At least three hydrophones are needed to determine an earthquake source location and an additional hydrophone is needed to calculate statistically meaningful location errors. The standard error for latitude, longitude and origin time is given by the output of the covariance matrix as modified by the mean-square residual (Fox et al. 2001). Within the HM10-11 array, 65 per cent of the events have an error in origin time lower than $2 \mathrm{~s}$ and 60 per cent have latitudinal and longitudinal errors less than $4 \mathrm{~km}$ (Fig. 2)
Hydroacoustic methods can often detect smaller magnitude earthquakes and derive epicentre locations with greater accuracy than land-based seismic stations (Pan \& Dziewonski 2005). However, earthquake focal depth and source parameters (Fox et al. 1994) cannot yet be determined from the $T$-wave signal packet. The Source Level (SL, acoustic magnitude) corresponds to the measure of the earthquake size and is expressed in $\mathrm{dB}$ re $1 \mu \mathrm{Pa} @ 1 \mathrm{~m}$ (Fox et al. 2001). Its value is estimated from the Receiver Level (RL, 

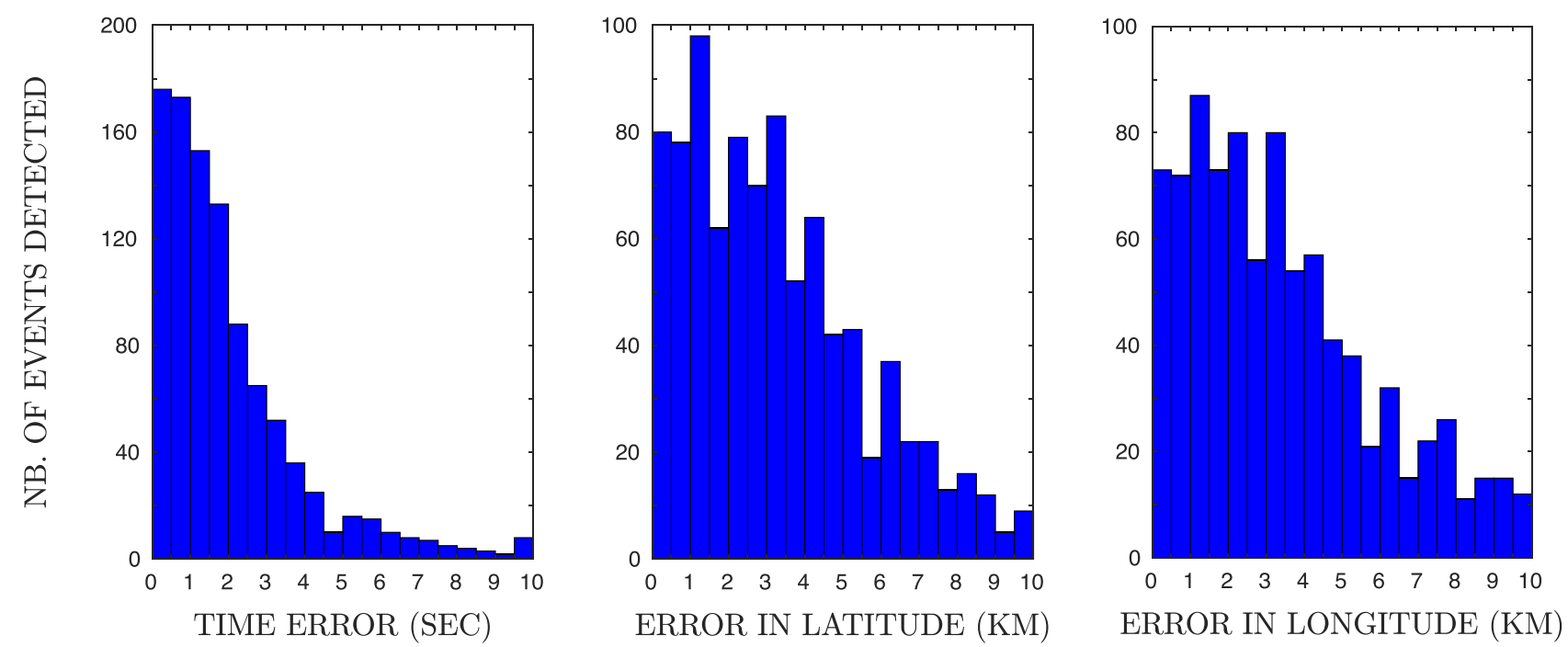

Figure 2. Histograms of the distribution of the errors (from left to right) in origin time, latitude and longitude of the event acoustic source location. The events occurred within the HM10-11 array and their locations were determined from the combined data of at least four AUHs.

expressed in $\mathrm{dB}$ re $1 \mu \mathrm{Pa}$ ) of the $T$-phase signal packet recorded at the hydrophone, the sensitivity value of the hydrophone (instrumental response, IR in $\mathrm{dB}$ re $1 \mu \mathrm{Pa}$ ) and the Transmission Loss (TL in $\mathrm{dB}$ re $1 \mathrm{~m}$ ) along the acoustic wave propagation path:

$\mathrm{SL}=\mathrm{RL}+\mathrm{TL}$,

where $\mathrm{RL}=20 \log _{10}\left(\frac{P}{P_{0}}\right)+\mathrm{IR}$ and

$$
\mathrm{TL}=20 \log _{10} \frac{R_{1}}{R_{0}}+10 \log _{10} \frac{R_{2}}{R_{0}} .
$$

The RL is calculated by calculating the spectrum energy or power of the $T$-phase signal in the frequency domain, which is equivalent to get the root-mean-square in the time domain, and includes the IR as well. The components $P$ and $P_{0}$ correspond to the recorded sound pressure and to the reference sound pressure in underwater acoustics $(1 \mu \mathrm{Pa})$, respectively. The TL is a sum of two terms representing the spherical and cylindrical spreading losses. Spherical spreading loss takes place during the propagation of the acoustic wave along the distance $R_{1}$ between the acoustic source at the seafloor and the SOFAR channel axis. The cylindrical loss is due to the propagation along the horizontal distance $R_{2}$ travelled by the acoustic wave within the SOFAR channel until it arrives to the receiver. Both losses are measured in $\mathrm{dB}$ units with respect to the reference distance $R_{0}$ of $1 \mathrm{~m}$.

The Source Level of completeness $\left(\mathrm{SL}_{\mathrm{c}}\right)$ corresponds to the minimum SL for which the AUH catalog is regarded as complete. This detection threshold is obtained in the same way as for the magnitude of completeness (Bohnenstiehl et al. 2002) and is estimated using a frequency-size relationship variation of the Gutenberg-Richter law (Gutenberg \& Richter 1944):

$\log _{10}(N)=a_{t}+b_{t} \mathrm{SL}_{\mathrm{c}}$,

where $N$ is the number of acoustic events with an SL greater or equal to the $\mathrm{SL}_{\mathrm{c}}$ and $a_{t}$ and $b_{t}$ are constants determined with the maximum likelihood method (Aki 1965). During the HM10-11 experiment, 1998 events were detected, of which 1429 were found to be located inside the array. The $\mathrm{SL}_{\mathrm{c}}$ estimated for only those 1429 events is equivalent to $206 \mathrm{~dB}$ re $1 \mu \mathrm{Pa} @ 1 \mathrm{~m}$ (Fig. 3a) and the roll-off point corresponds to $\sim 830$ events per year (Fig. 3a). The magnitude of completeness (Mslc) can be then extrapolated by the frequency-size distribution of the teleseismic events up to the number of events defining the $\mathrm{SL}_{\mathrm{c}}$ of the AUH network (Fig. 3b). We obtained an Mslc of $m_{\mathrm{b}}=2.4$ for the HM10-11 array.

A Single Link Cluster method (Frohlich \& Davis 1990) was used to identify the time-clustering behaviour of the seismicity during the August 2010 swarm using both the hydroacoustic and teleseismic earthquake catalogues. We used a space-time metric (ST-km) value $D$ to describe the proximity between events:

$D=\sqrt{d^{2}+t^{2}}$,

where $d$ is the distance in kilometres and $t$ is the time in decimal days, between two events. Nyffenegger \& Frohlich (2000) defined the cluster as the events located within a radius $D_{\mathrm{c}}=0.8 D_{1}$, where $D_{1}$ is the median link length of all $D$ within the event catalogue (in ST-km). We obtained $D_{1}=13.66$ ST-km, which is consistent with other values found in the MAR (Bohnenstiehl et al. 2002; Simao et al. 2010). The Single Link Cluster analysis reveals a cluster of 495 hydroacoustic events occurring from 10 August to 7 September. Our study will therefore focus on this event cluster.

We next developed a size-frequency relationship for the $T$-phase events (e.g. Bohnenstiehl et al. 2002) to obtain the $\mathrm{SL}_{\mathrm{c}}$ of this swarm. Our analysis results in an estimated $\mathrm{SL}_{\mathrm{c}}$ of $210 \mathrm{~dB}$ re $1 \mu \mathrm{Pa} @ 1 \mathrm{~m}$ (Fig. 4) for the studied cluster. We then employed a Modified Omori Law (MOL) to determine whether or not the FAMOUS seismic sequence/swarm follows a mainshock-aftershock time distribution (Utsu et al. 1995):

$N=K(c+t)^{-p}$.

Where $N$ is the cumulative number of events which occurred at the time $t$ after the main shock, $K, c$ and $p$ are empirically derived constants. $K$ reflects the total number of events in the sequence and the size of the main shock, $c$ is the rate of the activity at the beginning of the sequence and $p$ represents the aftershock decay rate. The software package SASeis (Statistical Analysis of Seismicity) was used to estimate these parameters, which employs a FletcherPowell optimization procedure (Utsu \& Ogata 1997) and maximum likelihood. An MOL was calculated using the second teleseismically recorded earthquake (04:11 GMT on 13 August) as the main shock 

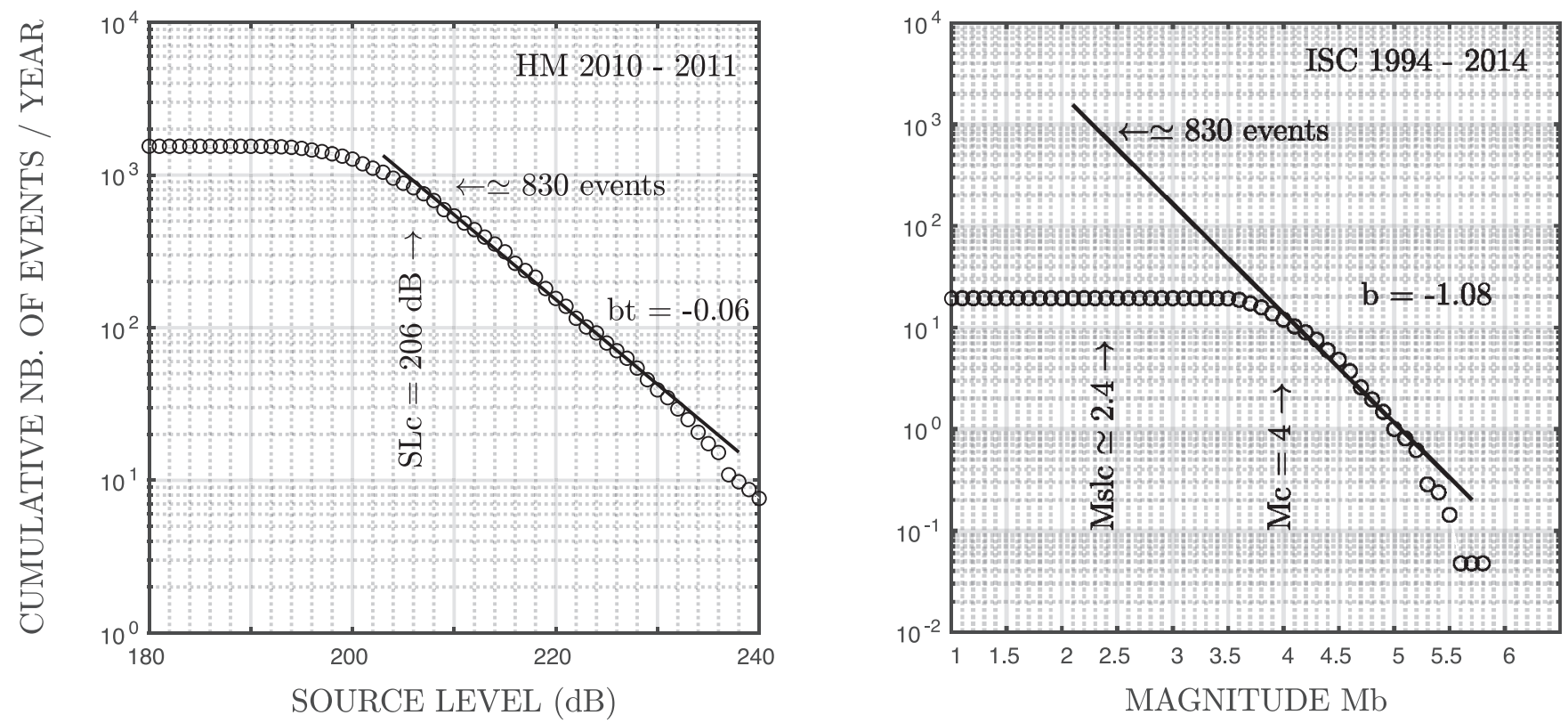

Figure 3. Size-frequency distribution (top) for the HM10-11 catalogue and (bottom) for the ISC teleseismic catalog. The magnitude of completeness (Mslc) shows that the threshold detection of the HM10-11 array is on the order of $m_{\mathrm{b}} \sim 2.4$.
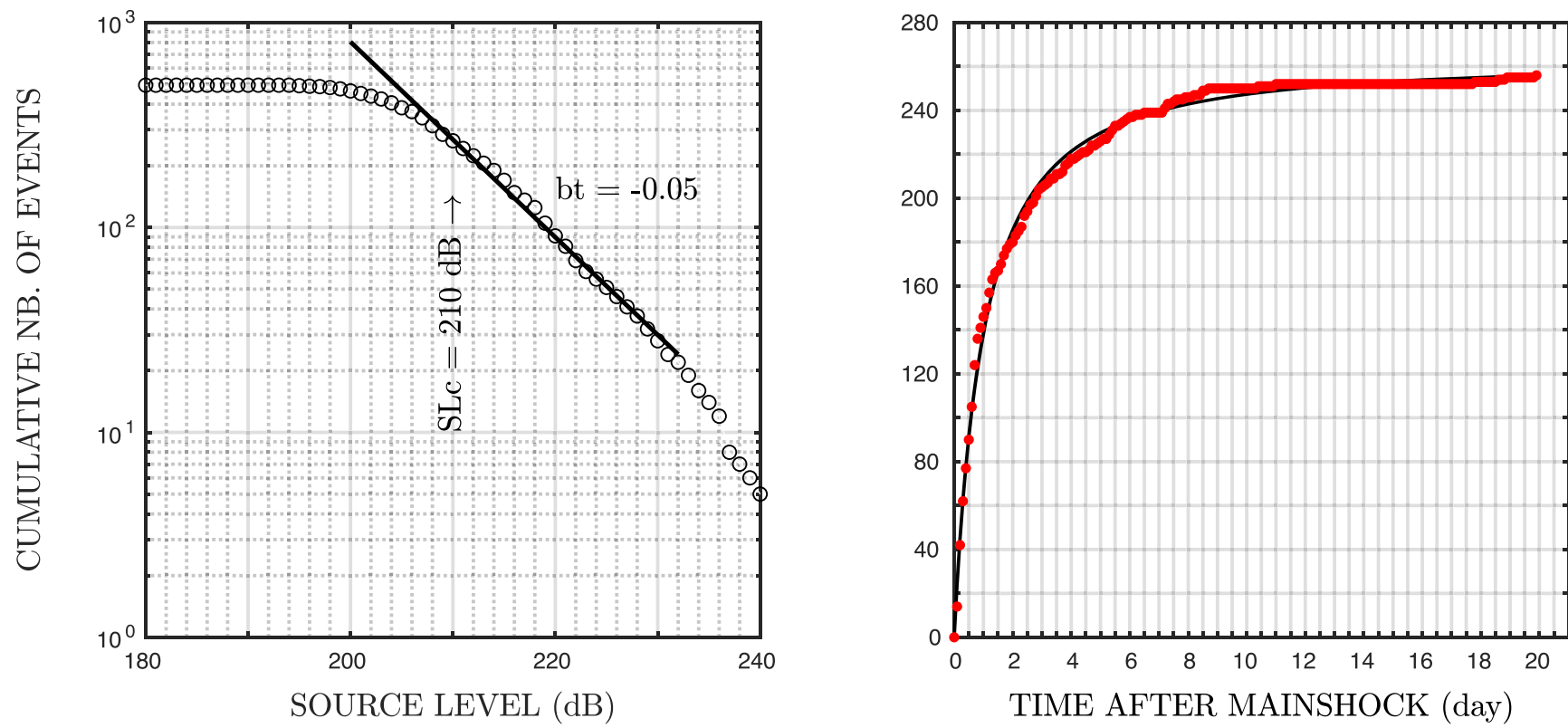

Figure 4. (Top) Frequency-size relationship for the August 2010 seismic sequence. (Bottom) Cumulative number of events (red dots) versus time after the main shock (4:11 GMT on the 2010 August 13) for earthquakes in the sequence with SL $\geq 210 \mathrm{~dB}$ re $1 \mu \mathrm{Pa} @ 1 \mathrm{~m}\left(\mathrm{SL}_{\mathrm{c}}\right)$. Predicted cumulative distribution for a mainshock-aftershock sequence deduced from the fit of the Modified Omori Law is indicated by the solid line.

(Fig. 4). This event was also the first teleseismic earthquake recorded by the hydrophone array, and had an SL of $242 \mathrm{~dB}$ re $1 \mu \mathrm{Pa} @ 1 \mathrm{~m}$.

The main onset of the swarm begins on 2010 August 13 with the appearance of high-energy, continuous, broad-band acoustic signals at 05:00 GMT, seen on all the AUHs (Figs 5c and d). Two AUHs closest to the earthquake swarm location (LS and M2, Fig. 1 inset) were chosen to show examples of the $T$-phase signals (Figs 5a and b) and their spectrograms (Figs 5c and d). High- (e.g. 4:11 GMT on 13 August) and low- (e.g. 4:00 GMT on the 14 August) energy earthquakes can be easily identified in the hydrophone signal and spectrograms (Fig. 5). The continuous energy present up to $80 \mathrm{~Hz}$ lasts for $\sim 31 \mathrm{hr}$ on the AUH-LS (Fig. 5c) and $\sim 20 \mathrm{hr}$ on the other AUHs (Fig. 5d). This same time duration for intrusion tremor was observed during the Lucky Strike swarm of 2001 (Dziak et al. 2004). In order to quantify and analyse the intensity variation of the broad-band signal, interearthquake energy was selected from each hydrophone spectrogram (Dziak et al. 2004) at 30 min intervals from 04:00 GMT to 10:00 GMT on 13 August and then each hour through to 14:00 GMT on 14 August. After 14:00 GMT on 14 August, this broad-band 'intrusion tremor' is not easily detectable on the spectrograms. In this respect, the RL of the intrusion tremor was obtained throughout this time period for each $\mathrm{AUH}$, while carefully 

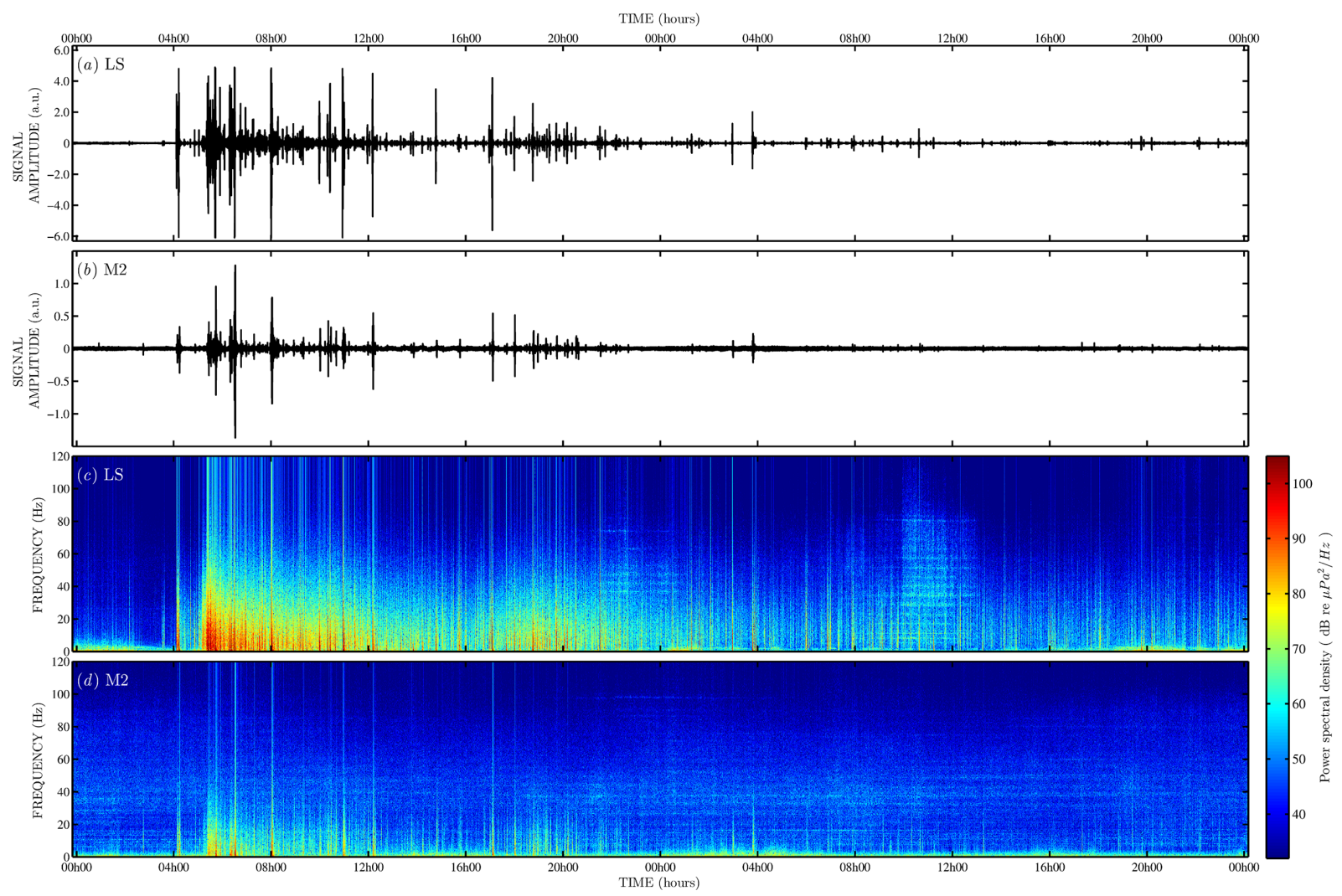

Figure 5. Time-series recorded by (a) the AUH-LS and (c) the AUH-M2 hydrophones. Both time-series start at 00:00 GMT on 2010 August 13 and end at 00:00 GMT on 2010 August 15. (b) and (d) display the corresponding spectrograms. Vertical axes of the time-series plots are in arbitrary units. The onset of a continuous broad-band acoustic energy $(1-80 \mathrm{~Hz})$ can be seen at 05:00 GMT.

avoiding $T$-wave energy. This analysis will be further discussed in Section 4.2.

\subsection{Gravimetric analysis}

The gravimetric data is able to provide an image of the structure of the FAMOUS area and a better understanding of the deep magmatic system driving the August 2010 swarm. Indeed, a thinner/colder and thicker/warmer crust should correspond to a positive/negative MBA, respectively, as shown by several previous studies (Detrick et al. 1995; Maia et al. 2007; Goslin et al. 2012).

Previous studies in the area provided regional MBAs calculated using the Parker spectral method (Parker 1973), smoothed with low-pass filters in order to remove the signal below a $30 \mathrm{~km}$ wavelength (Detrick et al. 1995; Cannat et al. 1999). The distribution of the gravimetric data profiles from the SUDACORES experiment (Cannat et al. 1999), however, allows calculating a higher resolution gravity model. To do so, calculation of the gravity effect of the topography and a constant thickness crust was done in the spatial domain using an improved prism method (Chapman 1979). In this method, the gravity effect of a prism calculated at any point location is given by

$$
g\left(x^{\prime}, y^{\prime}, z^{\prime}\right)=\rho \mathrm{G} \iiint \frac{\left(z-z^{\prime}\right) \mathrm{d} x \mathrm{~d} y \mathrm{~d} z}{\left(\left(x-x^{\prime}\right)^{2}+\left(y-y^{\prime}\right)^{2}+\left(z-z^{\prime}\right)^{2}\right)^{3 / 2}}
$$

where $\mathrm{G}$ is the Newtonian constant and $\rho$ the density of the body. The vertical direction $(z)$ is positive going up; primed coordinates
( $x^{\prime}, y^{\prime}$ and $\left.z^{\prime}\right)$ correspond to the observation point outside the prism and unprimed coordinates ( $x, y$ and $z$ ) are the integration variable. The bathymetry of the studied area is decomposed in several prisms with a square base, with a density of $1800 \mathrm{~kg} \mathrm{~m}^{-3}$, corresponding to the water/crust contrast. A second layer follows the bathymetry $6 \mathrm{~km}$ deeper and it is decomposed in similar square-based prisms with a density of $500 \mathrm{~kg} \mathrm{~m}^{-3}$, corresponding to the crust/mantle contrast. Each prism is comprised of facets. The volume integral of the eq. (6) is changed to a surface integral with the Stokes theorem which allows solution of the equation for each facet of the prism (according to the face plane, unit vector normal to the element). The gravity anomaly of the prism is then the sum of the results of all the facets. The grid used for the calculation has a variable resolution, according to the distance between the prism and the profiles where the effects are calculated. The centre of the bathymetric grid used has therefore a higher resolution $(350 \mathrm{~m})$, but is surrounded by a coarser grid $(1000 \mathrm{~m})$ to avoid the edge effects. The gravity effect of this multiprism density model was computed at each sample location of the seven profiles of the SUDACORES cruise.

\subsection{Structural analysis}

Fig. 6 displays a structural scheme of the North FAMOUS and FAMOUS area. Main tectonic structures have been inferred from bathymetric map (black lines, Fig. 6) and are based on previous studies (Macdonald 1977; Ramberg et al. 1977; Choukroune et al. 1978). The main scarps delimit the two MOR segments and the NTO between them (thicker black lines with fault facing direction, Fig. 6) while the main visible faults (black lines with fault facing 


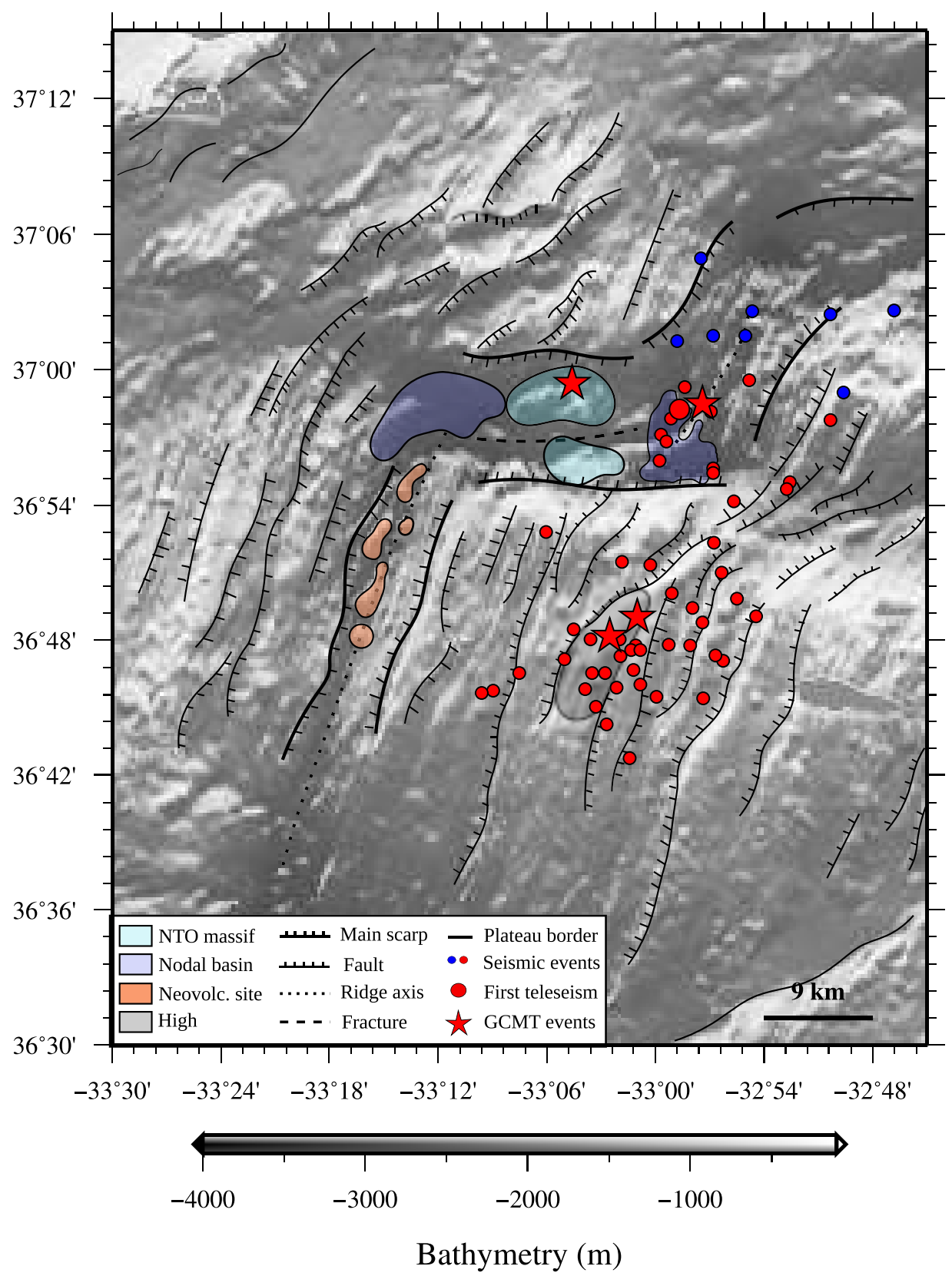

Figure 6. Interpreted geological structure of the North FAMOUS and FAMOUS segments. Acoustic source locations of the events comprising northward- and southward-migration sequences are indicated by blue and red dots, respectively. Bathymetric map (pixel resolution of $300 \mathrm{~m}$ ) is derived from several multibeam bathymetric surveys (Detrick et al. 1995; Cannat et al. 1999).

direction, Fig. 6) are represented on both segments flanks. Ridge axis of the North FAMOUS and FAMOUS segments are symbolized by dotted black lines and the main WSW/ENE strike-slip fault of the NTO is represented by a dashed black line (Fig. 6). West of the North FAMOUS segment and east of the FAMOUS segment, which are flanks of two volcanic plateaus formed during a significant episode of strong magmatism in Miocene time (Cannat et al. 1999), correspond to Jussieu Plateau and Princess Alice Bank borders (thin black lines, Fig. 6), respectively. NTO massifs and nodal basin locations are inferred from the bathymetric map and the morphostructural interpretation of Gracia et al. (2000). Dynamics of the swarm (red and blue symbols, Fig. 6) have been plotted as well and will be discussed further in Sections 4.2 and 5.2.

\section{TIMING AND DYNAMICS OF THE EARTHQUAKE SWARM}

\subsection{Hydroacoustic and teleseismic events}

The FAMOUS segment earthquake swarm began on 10 August at 3:07 GMT with 20 precursor events (Fig. 7) mainly located in the rift valley on the southwestern flank at the end of the North FAMOUS segment. Seismic activity increased substantially around 3:30 GMT on 13 August (Fig. 7). The spatial distribution of the 2010 earthquake swarm is not typical for MAR segments, and is mainly focused off-axis (Fig. 1). The $T$-waves source locations extend for more than $70 \mathrm{~km}$ across the NTO discontinuity (offset $\sim 20 \mathrm{~km}$ ) 

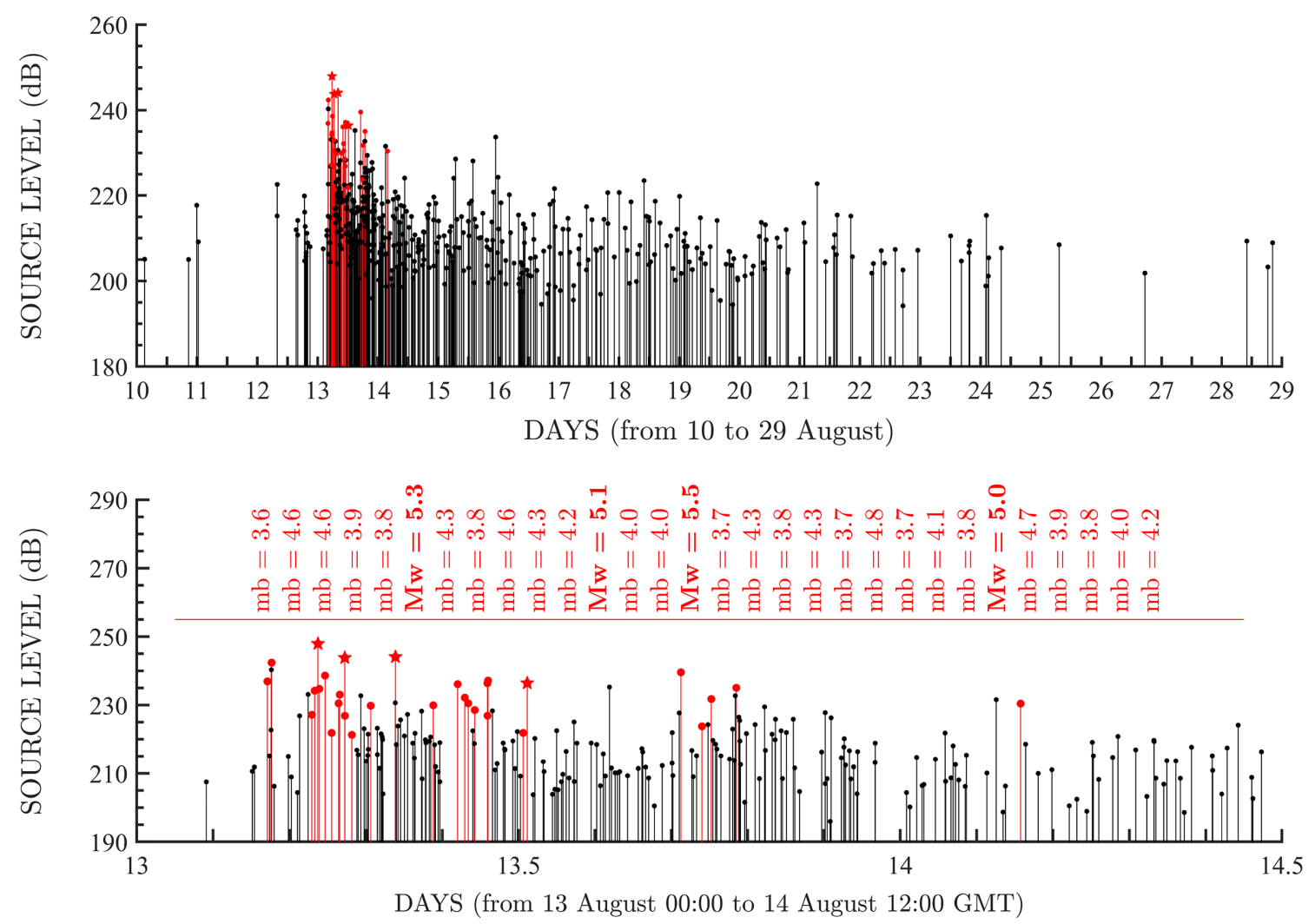

Figure 7. SL of the events of the August 2010 crisis versus time for the period (top) from 00:00 GMT on 2010 August 10 to 00:00 GMT on 2010 August 29 and (bottom) from 00:00 GMT on 2010 August 13 to 12:00 GMT on 2010 August 14 which provides a focus on the crisis peak. Black dots indicate the events detected only by at least three AUHs. Red dots indicate the events which were detected by both AUHs and land based stations. Red stars symbolize the four main shocks.

separating the $19 \mathrm{~km}$ long North FAMOUS segment and the $42 \mathrm{~km}$ long FAMOUS segment (Parson et al. 2000). The majority of the earthquakes are located on the outer walls, east and west of the FAMOUS and North FAMOUS segments, respectively, and along the North FAMOUS axial valley; only a few events are located east of the North FAMOUS segment (Fig. 1). Since the hydrophones surround the epicentres, this should reduce location bias due to the effect of 'topographic steering'. Moreover, the locations of the teleseismic events are distributed over more than $60 \mathrm{~km}$ (white triangles, Fig. 1). An elongated distribution of the hydroacoustic events of the swarm is correlated with an elongated shape of the teleseismic locations (Figs 1 and 9 bottom). More hydroacoustic events are detected south of the NTO because of the lower detecting threshold of the hydrophone array which is lower than the detection threshold of the teleseismic events.

During the peak in activity the entire network and AUH-LS detected 13 and $>120$ events per hour, respectively. The volcanoseismic crisis lasted at least 29 days with a peak of activity on 13 August (Fig. 7). Of the 495 hydroacoustic events located, 173 (35 per cent of the total) occurred on 13 August. A total of 30 teleseismic events (white triangles in Fig. 1 and red dots in Fig. 7) of magnitudes ranging from 3.6 to $5.3 m_{\mathrm{b}}$, were located by the International Seismological Centre (ISC 2013) between 13-14 August, with the first event occurring at 04:05 GMT $\left(m_{\mathrm{b}}=3.6\right)$ on $13 \mathrm{Au}-$ gust. The first teleseismic event was located on the western part of the spreading axis of the North FAMOUS segment (bigger red dot in Fig. 8), which is an area exhibiting negative MBA values meaning the presence of a warmer/thicker crust consistent with a magmatic source for the swarm (Plate 2b-Detrick et al. 1995). The four largest teleseismic earthquakes (Fig. 1) all occurred on 13 August and also have Global Centroid Moment Tensor solutions (GCMT, Ekström et al. 2012). We computed the non-double component of the moment tensor described by the parameter $\epsilon$ (Shuler et al. 2013) using the eigenvalues of the moment tensor solutions, where $\epsilon=0$ for double-couple earthquakes and $\epsilon= \pm 0.5$ for earthquakes that are purely Compensated-Linear-Vector-Dipoles (CLVD; Knopoff \& Randall 191970; Julian et al. 1998; Shuler et al. 2013). Two of these earthquakes are double-couple solutions $(\epsilon=0)$ associated with normal faulting (at 05:40 and 07:58, $M_{\mathrm{w}}=5.3$ and 5.5, respectively). One event $\left(06: 28, M_{\mathrm{w}} 5.1\right)$, however, is very close to a non-double-couple solution with a strong CLVD component $(\epsilon=0.42)$. Its mechanism could be consistent with fluid (magma) intrusion into the crust, and mostly dilatational earthquake mechanism. This will be further discussed in Section 5.1. The last event is very close to a double-couple solution $\left(12: 08, M_{\mathrm{w}}=5.0, \epsilon=0.06\right)$. The acoustic source location of the 5.3 event is along the southern axial valley of the North FAMOUS segment (Fig. 1). The 5.1 (with a high CLVD component) event occurred $50 \mathrm{~min}$ later, and its acoustic source location is on the central-northern flank of the non-transform discontinuity (Fig. 1). The 5.5 earthquake occurred $1.5 \mathrm{hr}$ later and its acoustic location is on the eastern outer wall of the FAMOUS segment (Fig. 1). The 5.0 earthquake (almost double-couple) has its acoustic location near the precedent GCMT earthquake (Fig. 1).

\subsection{Migration of the seismic activity}

The observed elongated shape of the earthquake location cluster, might suggest a migration of the earthquakes from a central point 


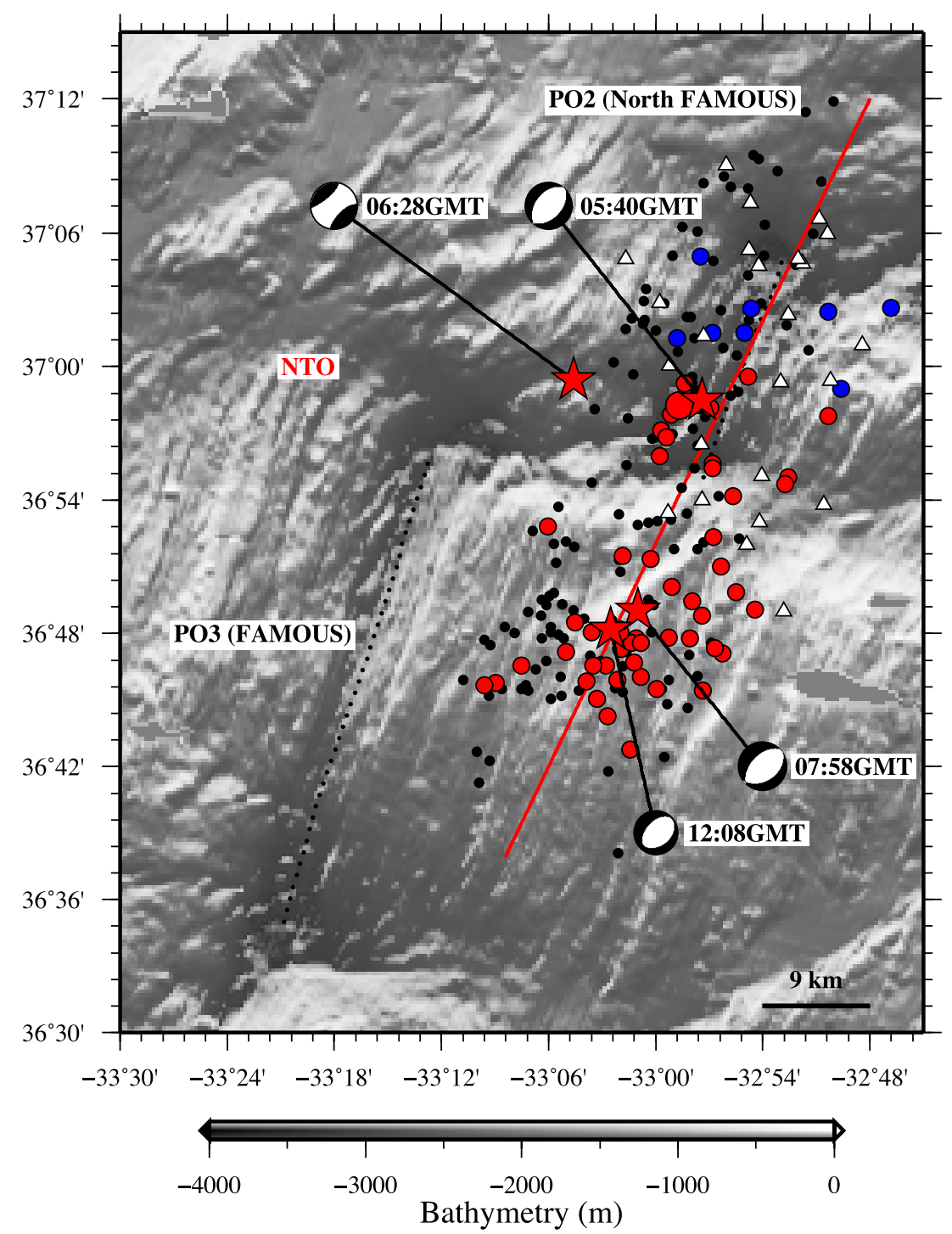

Figure 8. Bathymetric map derived from several multibeam bathymetric surveys (Detrick et al. 1995; Cannat et al. 1999) focused on the north FAMOUS (northern) and FAMOUS segments (southern). Earthquakes located using five AUHs, and with location uncertainties $\leq 4 \mathrm{~km}$ are represented. Events were projected onto the red line which follows the trend of the earthquake swarm. Events involved in the two episodes of migrations are symbolized by colour dots according to the migration direction (red for the southward one, blue for the northward one). The teleseismic epicentres (white triangles), the acoustic location of the first teleseismic event (big red dot) and the hydroacoustic epicentres (red stars) of the four main shocks associated to their moment tensor solutions (GCMT, Ekström et al. 2012) are also displayed.

(Fig. 1). To test this hypothesis, we projected the earthquakes that were located using at least four AUHs with location uncertainties $\leq 4 \mathrm{~km}$ (blacks dots, Fig. 8) onto a cross-section line parallel to the trend of the earthquake swarm (red line, Fig. 8). Only events that occurred in a $20 \mathrm{~km}$ window on either side of the profile were used.

Fig. 9 (bottom) shows the time-distance distribution of the $T$ phase events (colour dots) and the ISC events (white triangles). The position of the NTO is also shown (black line). Three outlines seem to emerge from this projection: a significant southward migration of the events (red symbols, Fig. 9 bottom), followed by a possible northward migration (blue dots, Fig. 9 bottom) and then subsequent background seismic activity (black dots, Fig. 9 bottom). The south and north migration distances of the earthquakes $(\sim 30$ and $\sim$ $10 \mathrm{~km}$, respectively) well exceed the event location errors $(\leq 4 \mathrm{~km})$, giving us confidence that those migrations are not artefacts. The event locations first propagate southwards, starting at 4:00 GMT on 13 August, covering $\sim 30 \mathrm{~km}$ over $\sim 9 \mathrm{hr}$ and ending at 13:40 GMT. Migration rate is estimated from the slope of a straight line obtained by a linear regression fit to the event locations (thick black dashed lines, Fig. 9 bottom), giving a rate of $0.7 \pm 0.1 \mathrm{~m} \mathrm{~s}^{-1}$ for the southward migration. At 13:40 GMT, the southward event migration ended $\sim 25 \mathrm{~km}$ south of the NTO under a bathymetric high along the western FAMOUS segment valley walls (Figs 6, 8 and 9 bottom). Then, in the same area where the southward migration began (thin dashed black line, Fig. 9 bottom), events appear to have propagated northward from 11:00 GMT to 16:00 GMT, covering a distance of $\sim 10 \mathrm{~km}$. The associated linear regression fit provides a migration rate of $0.4 \pm 0.2 \mathrm{~m} \mathrm{~s}^{-1}$. However, there are only eight events that characterize the northward migration, and therefore the northward migration is not as nearly well constrained as the southward one. By 16:00 GMT, no more migration of events was observed (black dots, Fig. 9 bottom) and a seismicity gap appeared from 20:00 GMT on 

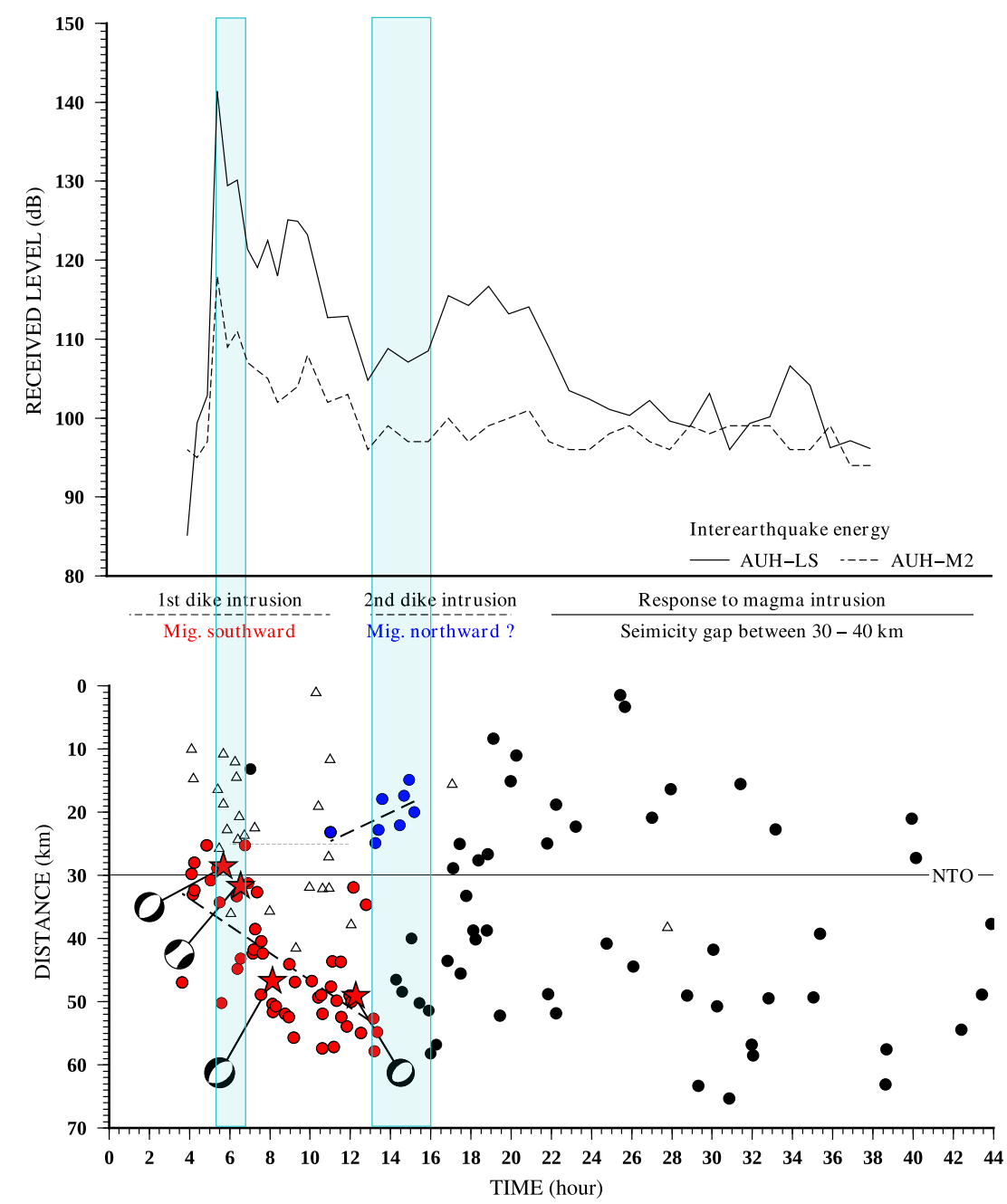

Figure 9. From 00:00 GMT on 2010 August 13 to 18:00 GMT on 2010 August 14. (Top) Acoustic received level (RL) versus time of the interearthquake energy selected from the broad-band signal each $30 \mathrm{~min}$ from 04:00 GMT to 10:00 GMT on 13 August and then each hour until 18:00 GMT on 14 August. Solid black line shows the result for AUH-LS and the dashed black line displays the one for the AUH-M2. (Bottom) Space-time distribution of the earthquake swarm projected along the profile (using five AUHs, and with location uncertainties $\leq 4 \mathrm{~km}$ ). Vertical axis is the distance in $\mathrm{km}$ along the profile of projection (oriented southwards). Red and blue dots represent the events which migrate (southwards and northwards, respectively), black dots correspond to the event with no migration pattern. Teleseismic earthquakes (white triangles) and large GCMT events (red stars) are also shown with their associated focal mechanisms. Possible migration patterns are indicated by dashed lines and migration rate determined by linear regression fit $\left(0.7 \pm 0.1\right.$ and $0.4 \pm 0.2 \mathrm{~m} \mathrm{~s}^{-1}$ southward and northward, respectively). Onset of both migrations seems to occur in the same area (thin grey dashed line).

13 August to 16:00 GMT on 14 August (hour 40 on Fig. 9), in the location of the NTO (Fig. 9 bottom).

\subsection{Broad-band spectrum signal}

Broad-band acoustic energy was previously observed during MOR dike intrusion events on the Juan de Fuca and MARs and was referred to as 'intrusion tremor' (Dziak \& Fox 1999a; Dziak et al. 2004). Intrusion tremor typically accompanies the rise of seismic activity of the swarm, and has been previously interpreted as the energy sum of all of the low-amplitude tremors and cracks caused by the movement of magma in the crust (Dziak et al. 2004). Fig. 9 (top) represents the interearthquake energy for the AUH-LS and AUHM2. Over a $30 \mathrm{~min}$ period from the onset of the broad-band energy, the RL increases from $100 \mathrm{~dB}$ re $1 \mu \mathrm{Pa}$ to more than $140 \mathrm{~dB}$ re 1 $\mu \mathrm{Pa}$ on AUH-LS and from $100 \mathrm{~dB}$ re $1 \mu \mathrm{Pa}$ to $120 \mathrm{~dB}$ re $1 \mu \mathrm{Pa}$ on AUH-M2 (first light blue rectangle, Fig. 9 top). A main peak energy level can be observed at 05:30 GMT on both curves and coincides in time with the highest SL earthquake of the swarm detected by the AUH array (05:40 GMT-Fig. 7), which is also the first normal faulting event. The third teleseismic earthquake (normal fault solution) occurred in the middle of the southward-earthquake migration and caused an increase in the intrusion tremor signal. After this event, the interearthquake energy began to decrease overall, until 13:40 GMT. This time is associated with the end of the southward migration. This minimum energy value occurred a few minutes after the last event with a known GCMT solution. The possible northward migration, located in the same area as the first intrusion (thin dashed grey line, Fig. 9 bottom), seems to be linked to the onset of an increase in the broad-band energy. This increase continued until the seismicity gap around 20:00 GMT (second light blue rectangle, Fig. 9 top). Once the northward migration was over, the interearthquake energy level slowly decreased until the RL dropped below $100 \mathrm{~dB}$ re $1 \mu \mathrm{Pa}$ (Fig. 9 top). After the southward- and northward-migration episodes the seismic activity was distributed over both the south and 


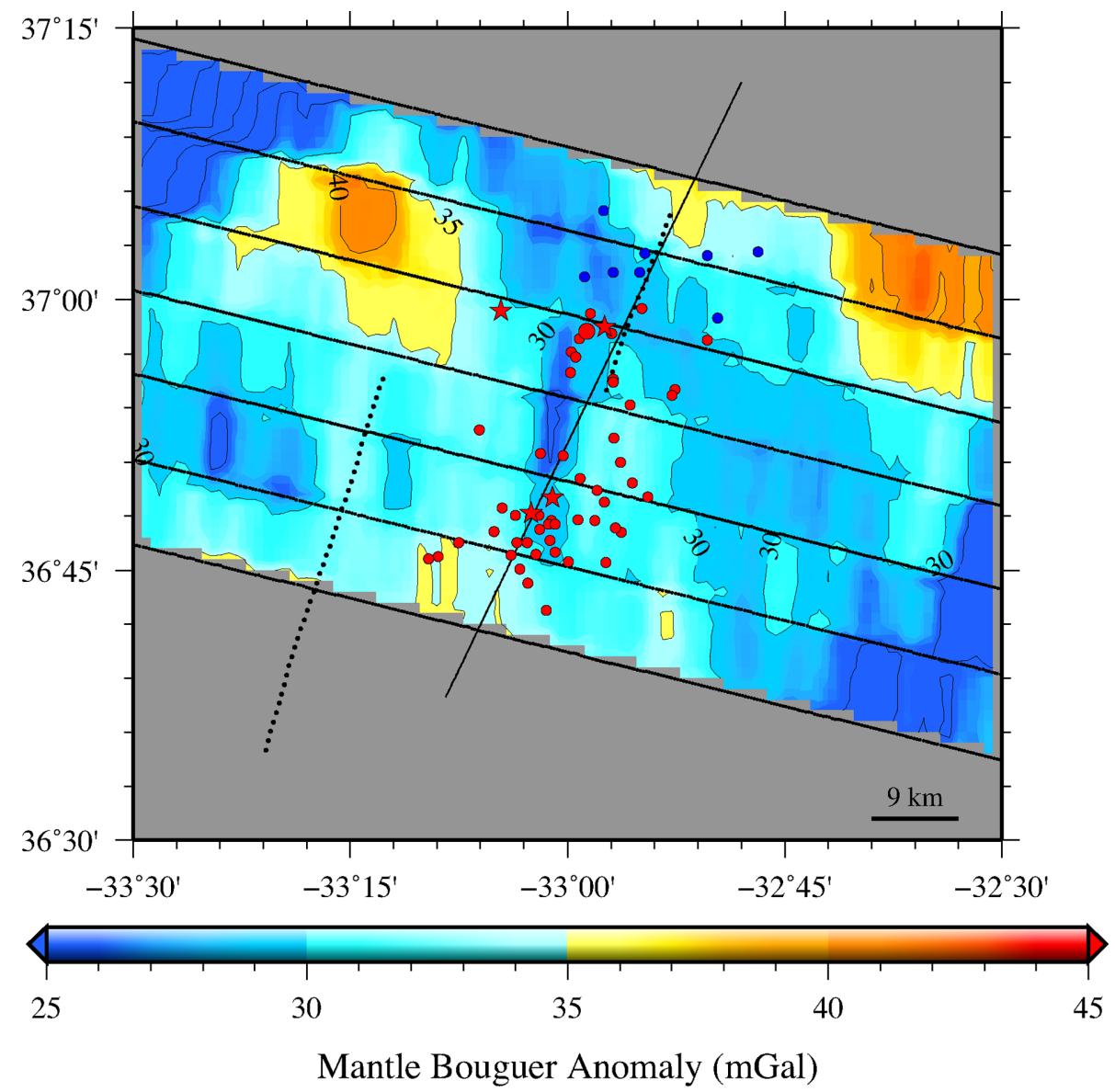

Figure 10. High-resolution MBA map displays the result of the gravimetric analysis computed through the calculation of the geoid anomalies (Chapman 1979) and the gravimetric data of the seven profiles of the SUDACORES experiment (thick oblique black lines; Cannat et al. 1999). The MBA values are relative. The axial valleys of the North FAMOUS and FAMOUS segments are represented by the dotted lines. Earthquakes involved in the two episodes of migration are represented by coloured dots, where red and blue indicate southward and northward propagation, respectively. Migration direction is shown by the thin black line. The acoustic location of the first teleseismic event (big red dot) and the hydroacoustic epicentres (red stars) of the four main shocks associated to their moment tensor solution (GCMT, Ekström et al. 2012) are also displayed.

north areas of the NTO. Through the end of August, no evidence of other migration episodes was observed. However, seismicity continued intermittently throughout the NTO and likely represented the crustal stress readjustment to the magmatic intrusion (Fig. 9 bottom).

\subsection{Modified Omori law}

Fig. 4 shows the MOL analysis applied to the swarm and the cumulative number of earthquakes as a function of time for the events with an SL $\geq 210 \mathrm{~dB}$ re $1 \mu \mathrm{Pa} @ 1 \mathrm{~m}$. The parameters associated with the MOL (Utsu et al. 1995) obtained for our sequence are $K=502.3 \pm 386.6, c=1.3 \pm 0.4$ and $P=2.3 \pm 0.3$. An AndersonDarling statistic $\left(A^{2}\right)$ has been computed to evaluate the goodness of fit of the MOL function. The obtained value $\left(A^{2}=1.009\right)$ indicates that the sequence's distribution is represented by a mainshockaftershock sequence (Bohnenstiehl et al. 2002). The high $K$-value also indicates a high level of background seismicity, which could be caused by the numerous swarm-style earthquakes associated with the dike intrusions (migration of the lava flow propagating through pre-existing ruptures) or produced by the reactivation of small fractures (Toda et al. 2002). According to Utsu et al. (1995), an average p-value is generally near 1.1 , with a range of variability between
0.6 and 2.5. Our p-value estimate falls at the higher end of this interval. High p-values $(P>1)$ reflect rapid strain release where a rapid aftershock rate decay might result from high-hypocentral temperatures (Bohnenstiehl et al. 2002; Klein et al. 2006). In this way, our high p-value could be interpreted as an evidence of high-crustal temperatures, which lead to fewer aftershocks in the sequence (Fig. 4). Two of the sequences described by Simao et al. (2010) have pvalues $(P=2.7$ and 2.3$)$ similar to the value obtained in our study. Detachment faulting associated with asymmetric accretion can also generate high p-value (Simao et al. 2010) as well as hydrothermal fluid movement which can reduce the strength of fault zones (i.e. serpentinization; Goslin et al. 2005; Simao et al. 2010).

\subsection{Gravimetric results}

Fig. 10 displays the MBA calculated using the prism model previously described and the seven profiles of the SUDACORES cruise (thick oblique black lines; Cannat et al. 1999). The axial valleys of the North FAMOUS and FAMOUS segments are represented by dotted lines. Two areas of low MBA value emerge off-axis and are associated to the two flanks of the Jussieu Volcanic Plateau formed during an episode of strong magmatism in the Miocene (Cannat et al. 1999). Moreover, the west flanks of both the North FAMOUS 
and FAMOUS segments reveal two other areas of low MBA value, already visible on the MBA calculated by Detrick et al. (1995; Plate 2a). The most remarkable observation on Fig. 10 is the presence of an elongated-low MBA value area, which crosses the NTO and extends through the eastern wall of the FAMOUS segment. Earthquakes involved in the two episodes of migration tend to cluster around this structure, straddling the southern segment on its northern ends. These observations will be later discussed in Sections 5.2 and 5.3.

\section{DISCUSSION}

\subsection{Spatio-temporal evolution of the crisis}

Overall, we interpret the dynamics and spatio-temporal distribution of the August 2010 earthquake swarm at the North FAMOUS and FAMOUS segments as an evidence of magmatic accretion at the slow spreading MAR. There was a small cluster of precursor earthquakes $\sim 2 \mathrm{~d}$ before the start of the main seismic sequence, but these are mostly low SL $(<220 \mathrm{~dB}$ re $1 \mu \mathrm{Pa} @ 1 \mathrm{~m})$ events and their relationship to the initiation of the magmatic event is not clear (Fig. 7). These earthquakes could have changed the stress regime in the crust, changing the overpressure on the magma body, and triggering the magma injection event (Baer et al. 2008). The partitioning between tectonic and magmatic events is not always obvious, as the broad-band intrusion signal is intermixed and occurs at the same time as the large magnitude, seemingly tectonic, earthquakes. According to Rubin \& Gillard (1998), the extent of seismicity during an intrusion reflects seismicity on pre-existing faults that were in an ambient stress close to failure. We propose that during the dike propagation, stress changes induced large GCMT earthquakes by reactivation of faults. Given that dike intrusion and propagation alters the ridge-crest stress field causing slip on the boundary wall normal faults located above and ahead of the intrusions (Rubin 1992; Rubin \& Gillard 1998), we suggest that the southward-lateral magma emplacement (Figs 8 and 9 bottom) likely resulted in the first teleseismically recorded earthquake at 04:06 GMT on 13 August $\left(m_{\mathrm{b}}=3.6\right)$ as the initiation of the magma intrusion, coinciding also with the onset of the broad-band energy signal (intrusion tremor, Fig. 9). Then, the faulting, and therefore the change in the local crustal stress regime induced by this large earthquake, could have reactivated pathways in the crust which allowed the magma to begin propagating into pre-existing fissures, cracks and pore spaces, creating this broad-band signal energy. The second GCMT event occurred simultaneously with the peak in intrusion tremor (Fig. 9). This event, close to a non-double-couple solution, has a moment tensor with a strong CLVD component. Previous studies of the mechanisms of non-double-couple earthquakes (Frohlich 1994, 1995) suggest that the corresponding focal mechanism of the $06: 28$ GMT event might be consistent with eq. (1) a dilatational earthquake mechanism generated by dike injection, or eq. (2) caused by a slip along a curved surfaces (Frohlich et al. 1989; Frohlich 1990) or eq. (3) could be the sum of ridge-normal and transform strikeslip events (Kawakatsu 1991). The second GCMT event is located in the northern NTO massif of the NTO (Fig. 6). Knowing that these massifs (northern and southern) are characterized by curved, irregular and discontinuous pattern (Gracia et al. 2000), we suggest that the focal mechanism of this large earthquake was likely generated by either source parameter option (1) or (2). Both the third and last GCMT events also likely represented the normal faulting in response to the stress perturbation caused by the dike propagation (Toda et al. 2002, Shuler \& Nettles 2012)

\subsection{Seismicity and diking intrusions}

Migration of seismic activity and earthquake locations has been observed at both subaerial and submarine MORs, and has been attributed to the vertical and/or lateral injection of a magma dike at the ridge axis (e.g. Bransdodttir \& Einarsson 1980; Dziak et al. 1995; Dziak \& Fox 1999b; Dziak 2001; Bohnenstiehl et al. 2004; Tsang-Hin-Sun et al. 2016). To our knowledge this swarm is one of the largest magmatic earthquake swarms recorded on the northern MAR. It occurred $9 \mathrm{yr}$ after the magma intrusion at Lucky Strike segment (Dziak et al. 2004), the MAR segment directly north of the North FAMOUS segment. The North FAMOUS-FAMOUS earthquake swarm is very similar to magmatic intrusion earthquake swarms observed previously at Lucky Strike segment (Dziak et al. 2004), Gakkel Ridge (Tolstoy et al. 2001), as well as other intrusion events with direct volcanic observation, such as Axial Seamount (Dziak \& Fox 1999a,b), CoAxial segment (Dziak et al. 1995), Krafla Volcano in Iceland (Brandstottir \& Einarsson 1980, 1992) and in the western part of the Gulf of Aden (Ahmed et al. 2016). Each of these other MOR volcano-seismic episodes was accompanied by a lowfrequency broad-band intrusion tremor. Also, large ranges in dike propagation rates have also been observed, ranging from $0.002 \mathrm{~m}$ $\mathrm{s}^{-1}$ (Tolstoy et al. 2001) to $1.2 \mathrm{~m} \mathrm{~s}^{-1}$ (Brandsdottir \& Einarsson 1980). Southward- and northward-migration rates observed during the swarm of August 2010 in the FAMOUS area are close to the ones observed for the ridges of intermediate spreading rates, such as Gorda Ridge in $1996\left(0.55 \mathrm{~m} \mathrm{~s}^{-1}\right.$, Fox \& Dziak 1998) and CoAxial segment (Juan de Fuca Ridge) in 1993 (0.3 $\mathrm{m} \mathrm{s}^{-1}$, Dziak et al. 1995).

We suggest that the two earthquake migration patterns observed during the North FAMOUS-FAMOUS swarm, propagating southwards and northwards are caused by two different magma dike intrusions, reaching approximate lengths of 30 and $10 \mathrm{~km}$, respectively. Nevertheless, these two lengths might be smaller than the migration of the seismic activity which could be longer due to seismicity occurring ahead of lateral diking propagation (Rubin 1992; Rubin \& Gillard 1998; Toda et al. 2002). Interestingly, a change of the direction of dike propagation was also observed at the Axial Seamount for the 2015 eruption (Wilcock et al. 2016) and in the Gulf of Aden (Ahmed et al. 2016). In the case of the Axial Seamount, Dziak \& Fox $(1999 a, b)$ suggested that the cessation of dike migration at the distal end of a rift zone could be caused by oblique faults, cutting the ridge-axis, that acts as structural or stress barriers to magma movement. Moreover, for the Axial Seamount (Dziak \& Fox 1999aa,b) and Gulf of Aden (Ahmed et al. 2016) intrusion events, the magma migration began from the centre of the segment and propagated to one or both distal segment ends. The southward migration at the North FAMOUS and FAMOUS segments has similar dynamic and geometric parameters (speed of the migration and geometry of the migration parallel to the rift axis), whereas the propagation of seismicity started near the NTO. However, no structures are clearly visible from the North FAMOUS-FAMOUS bathymetry (Fig. 6) or identified in the literature that can explain the change in dike migration observed during the August 2010 swarm.

While it is possible that the magma intrusion could have reached the surface, and even erupted onto the seafloor, no in situ evidence 
exists to confirm that a seafloor eruption occurred. The border between the northward and southward migration (Figs 6 and 8) corresponds to the low MBA on the west side of the North FAMOUS segment (Fig. 10; Plate 2b-Detrick 1995), indicating the presence of a warmer/thicker crust consistent with a magmatic source for the swarm. Furthermore, evidence exists that this area with low MBA values has experienced multiple dike intrusions in the recent geological past (Fig. 6; Choukroune et al. 1978; Gracia et al. 2000; Parson et al. 2000).

Dike emplacements along the MAR have been described as originating from small pockets, or lenses, of magma (Tolstoy et al. 2001; Dziak et al. 2004) or possibly a well-established magma reservoir depending on the type of volcanic system (Dziak \& Fox 1999b; Einarsson 1991). According to Detrick et al. (1990), contrary to the fast spreading ridges, there is no continuous crustal magma chamber along the MAR, but rather discrete and/or ephemeral magma chambers or small magma lenses. Indeed, several authors (Sinton \& Detrick 1992; Cannat 1993; Barclay et al. 1998; Magde et al. 2000; Gac et al. 2003, 2006) describe 3-D crustal melt delivery system models of oceanic accretion at slow spreading ridge beneath the segments. Small melt pockets deliver the magma by short-lived intrusive bodies. Moreover, Aki (1984) proposed a four-step model to explain the source of an earthquake caused by magmatic intrusion. Two magma-filled cracks separated by a closed channel which is then opened due to arrival of magma overpressure in one of the cracks. The connection of the two magma sills and the corresponding magma displacement will lead to a decrease in the magma pressure due to an increase in crack volume. Thus, an alternative explanation may be that the lateral dike propagation may simply be an open conduit between two magma sills in the FAMOUS area.

\subsection{NTO and diking intrusions}

The southward event migration crosses the NTO, between the North FAMOUS and FAMOUS segments, suggesting that the NTO is not a strong lithospheric barrier unlike the large offset discontinuities which act as more significant barriers to ridge propagation/migration (Dannowski et al. 2018). The low MBA values colocated with the earthquakes support this hypothesis (Fig. 10). The MBA values are interpreted to represent lower crustal density, a thicker crust and a potentially higher thermal anomaly, but cannot be considered as an evidence of the presence of melt in the area where the swarm initiated at the west end of the North FAMOUS segment (Fig. 2). The off-axis propagation of the swarm across the NTO through to the eastern wall of the FAMOUS segment is somewhat unexpected for a slow-spreading MOR and seems to indicate that NTOs are not strong barriers to magma movement. NTOs are 'non-rigid' offsets which can migrate, leading to a reduction or expansion of the bounded spreading segments (Gente et al. 1995; Maia \& Gente 1998). The north and south NTOs of the FAMOUS segment are not in steady state and evolve through time (Ramberg et al. 1977; Choukroune et al. 1978). Ramberg et al. (1977) describe recent northward migration (which occured in the past 2 m.y.) of the south FAMOUS segment NTO. Another case of NTO migration has also been observed recently along the MAR at $21.5^{\circ} \mathrm{N}$ (Dannowski et al. 2018).

As a follow up to the study by Choukroune et al. (1978), Goud \& Karson (1985) extended the study of the FAMOUS area to the south NTO using deep-towed camera system and submersible observations. The NTO between the FAMOUS and Amar segments is a similar offset in terms of dimension, but displays evidence of volcanic activity very close to the western nodal basin (Goud \& Karson 1985). Moreover, a high volcanic ridge south of the FAMOUS segment extends $200 \mathrm{~m}$ in this nodal basin and also displays recently erupted, unfractured basalt pillows and flow structures supporting the presence of volcanism at the NTO (Goud \& Karson 1985). Evidence of magmatic activity within NTOs has been described at other location along the MAR, for example, at the Rainbow ultramafic massif located between the Amar Minor N and Amar Minor S segments (Paulatto et al. 2015; Eason et al. 2016). Using seismic imaging, Canales et al. (2107) revealed the presence of a large number of magmatic sills through the Rainbow massif, which explains the high-temperature hydrothermal systems in this area. Even if this magma supply here is low, it provides evidence of magmatic activity within an NTO context.

\section{CONCLUSIONS}

To our knowledge, the swarm reported in this paper is one of the largest magmatic $T$-phase earthquake sequences recorded on the northern MAR, and may be the first intrusion event detected along the northern MAR since the Lucky Strike segment intrusion in 2001. Unlike the Lucky Strike episode, this sequence exhibited a fewer number of teleseismically detected earthquakes (with four large earthquakes with moment tensor solutions) and was dominated by low magnitude seismicity. Even though no previous evidence of recent volcanism has been observed at the nodal basin south of North FAMOUS segment, we interpret this earthquake sequence as likely being of volcano-magmatic origin and caused by the lateral propagation of two magma dikes, the first southward, the second northward. A continuous broad-band acoustic energy accompanied the earthquake sequence and is interpreted as the intrusion tremor resulting from lava flowing through pre-existing fractures/fissures in the shallow ocean crust. The southward migration of the seismicity is unusual because it crosses the NTO separating the north FAMOUS and FAMOUS segments. High-resolution gravimetric analysis shows the presence of an elongated structure of low MBA values with the same orientation as the southward-earthquake migration pattern, reinforcing the idea that the NTO is not a structural barrier to magma propagation.

\section{ACKNOWLEDGEMENTS}

The authors wish to thank the captain and crews of HYDROBSMOMAR 2010 \& HYDROBS-MOMAR 2011 experiments for their help and seamanship during the successful deployments and recoveries of the AUHs. MG received financial support from the Université de Bretagne Occidentale and the Regional Council of Brittany. AS received financial support from CNRS Chair of Excellence award. This work was financially supported by the French 'Agence Nationale de la Recherche' through the 'Laboratoire d'Excellence' LabexMER (ANR-10-LABX-19-01) program, and cofunded by a grant from the French government through the 'Investissements d'Avenir' and by EMSO-Açores. A special word of thanks is addressed to J. F. D'Eu, designer of the AUHs, C. Brachet who carried out the operations of deployment and recovery of AUHs and T.-K. Lau who developed the $T$-phase analysis software and provided valuable tips. Maps were made with the Generic Mapping Tool (Wessel et al. 2013). This paper is NOAA/PMEL Contribution Number 4694. We would like to thank Kulvinder Chadha (assistant Editor), Delwayne Bohnenstiehl and another anonymous reviewer 
for the review of the manuscript and for their constructive critics, which greatly contributed to improve the paper.

Author contributions: JP designed the HYDROBS-MOMAR experiments $(2010,2011)$. JP, AS and MM collected the hydrophones data. AS worked on the signal processing. MG analysed the data and produced the figures. MG, JP and RPD interpreted the data. MG, RPD wrote the paper. MG, JP, RPD, AS and MM revised it critically for important intellectual content.

\section{REFER ENCES}

Ahmed, A. et al., 2016. Seafloor spreading event in western Gulf of Aden during the November 2010-March 2011 period captured by regional seismic networks: evidence for diking events and interactions with a nascent transform zone, Geophys. J. Int., 205, 1244-1266.

Aki, K., 1965. Maximum likehood estimate of $\mathrm{b}$ in the formula $\log \mathrm{n}=\mathrm{a}$ bM and its confidence limits, Bull. Earthq. Res. Inst., 43, 237-239.

Aki, K., 1984. Evidence for magma intrusion during the Mammoth Lakes Earthquakes of May 1980 and implications of the absence of volcanic (harmonic) tremor, J. geophys. Res., 89(B9), 7689-7696.

Baer, G., Hamiel, Y., Shamir, G. \& Nof, R., 2008. Evolution of a magmadriven earthquake swarm and triggering of the nearby Oldoinyo Lengai eruption, as resolved by InSAR, ground observations and elastic modeling, East African Rift, 2007, Earth planet. Sci. Lett., 272, 339-352.

Ballard, R.D. \& Van Andel, T.H., 1977. Morphology and tectonics of the inner rift valley at Lat $36^{\circ} 50^{\prime} \mathrm{N}$ on the Mid-Atlantic Ridge, Bull. geol. Soc. Am., 88, 507-530.

Ballard, R.D., Bryan, W.B., Heirtzler, J.R., Keller, G., Moore, J.G. \& Van Andel, T.H., 1975. Manned submersible observations in FAMOUS areaMid-Atlantic Ridge, Science, 190(4210), 103-108.

Barclay, A.H., Toomey, D.R. \& Solomon, S.C., 1998. Seismic structure and crustal magmatism at the Mid-Atlantic Ridge, $35^{\circ} \mathrm{N}, J$ geophys. Res., 103(B8), 17 827-17 844.

Bergman, E.A. \& Salomon, S.C., 1990. Earthquake swarm on the MidAtlantic Ridge: products of magmatism or extensional tectonics?, J. geophys. Res., 95(B4), 4943-4965.

Bohnenstiehl, D.R., Tolstoy, M., Dziak, R.P., Fox, C.G. \& Smith, D.K., 2002. Aftershock sequences in the mid-ocean ridge environment: an analysis using hydroacoustic data, Tectonophysics, 354, 49-70.

Bohnenstiehl, D.R., Dziak, R.P., Tolstoy, M., Fox, C.G. \& Fowler, M., 2004. Temporal and spatial history of the 1999-2000 Endeavour Segment seismic series, Juan de Fuca Ridge, Geochem. Geophys. Geosyst., 5(9), Q09003.

Brandsdottir, B. \& Einarsson, P., 1980. Seismological evidence for lateral magma intrusion during the July 1978 deflation of the Krafla Volcano in NE-Iceland, J. Geophys., 47, 160-165.

Brandsdottir, B. \& Einarsson, P., 1992. Volcanic tremor and low-frequency earthquakes in Iceland, in IAVCEI Proceedings in Volcanology, pp. 212222, eds Gasparini, P., Scarpa, R. \& Aki, K., Springer-Verlag.

Canales, J.P., Dunn, R.A., Arai, R. \& Sohn, R.A., 2017. Seismic imaging of magma sills beneath an ultramafic-hosted hydrothermal system, Geology, 45(5), 451-454.

Cannat, M., 1993. Emplacement of mantle rocks in the seafloor at Mid-ocean ridges, J. geophys. Res., 98, 4163-4172.

Cannat, M. et al., 1999. Mid-Atlantic Ridge-Azores hotspot interactions: along-axis migration of a hotspot-derived event of enhanced magmatism 10 to 3 Ma ago, Earth planet. Sci. Lett., 173(3), 257-269.

Chapman, M.E., 1979. Techniques for interpretation of geoid anomalies, $J$. geophys. Res., 84(B8), 3793-3801.

Choukroune, P., Francheteau, J. \& Le Pichon, X., 1978. In situ structural observations along Transform Fault A in the FAMOUS area, Mid-Atlantic Ridge, Bull. geol. Soc. Am., 89, 1013-1029.

Dannowski, A., Morgan, J.P., Grevemeyer, I. \& Ranero, C.R., 2018. Enhanced mantle upwelling/melting caused segment propagation, Oceanic Core Complex die off, and the death of a transform fault - the Mid-Atlantic Ridge at $21.5^{\circ} \mathrm{N}, J$. geophys. Res., 123(2), 941-956. de Groot-Hedlin, C.D. \& Orcutt, J.A., 2001. Excitation of T-phases by seafloor scattering, J. acoust. Soc. Am., 109(5), 1944-1954.

Detrick, R.S., Mudie, J.D., Luyendyk, B.P. \& MacDonald, K.C., 1973. Nearbottom observations of an active transform fault: Mid-Atlantic Ridge at $37^{\circ} \mathrm{N}$, Nature, 246, 59-61.

Detrick, R.S., Mutter, J.C., Buhl, P. \& Kim, I.I., 1990. No evidence from multichannel reflection data for a crustal magma chamber in the MARK area on the Mid-Atlantic Ridge, Nature, 347, 61-64.

Detrick, R.S., Needham, H.D. \& Renard, V., 1995. Gravity anomalies and crustal thickness variations along the Mid-Atlantic Ridge between $33^{\circ} \mathrm{N}$ and $40^{\circ} \mathrm{N}, J$. geophys. Res., 100(B3), 3767-3787.

Dziak, R.P., 2001. Empirical relationship of T-wave energy and fault parameters of northeast Pacific Ocean earthquakes, Geophys. Res. Lett., 28(13), 2537-2540.

Dziak, R.P. \& Fox, C.G., 1999a. The January 1998 earthquake swarm at Axial Volcano, Juan de Fuca Ridge: hydroacoustic evidence of a seafloor volcanic activity, Geophys. Res. Lett., 26(23), 3429-3432.

Dziak, R.P. \& Fox, C.G., 1999b. Long-term seismicity and ground deformation at Axial Volcano, Juan de Fuca Ridge, Geophys. Res. Lett., 26(24), 3641-3644.

Dziak, R.P., Fox, C.G. \& Schreiner, A.E., 1995. The June-July 1993 seismoacoustic event at CoAxial segment, Juan de Fuca Ridge: evidence for a lateral dike injection, Geophys. Res. Lett., 22, 135-138.

Dziak, R.P., Smith, D.K., Bohnenstiehl, D.R., Fox, C.G., Desbruyeres, D., Matsumoto, H., Tolstoy, M. \& Fornari, D.J., 2004. Evidence of a recent magma dike intrusion at the slow spreading Lucky Strike segment, MidAtlantic Ridge, J. geophys. Res., 109(B12).

Eason, D.E., Dunn, R.A., Canales, J.P. \& Sohn, R., 2016. Segment-scale variations in seafloor volcanic and tectonic processes from multibeam sonar imaging, Mid-Atlantic Ridge Rainbow region $\left(35^{\circ} 45^{\prime}-36^{\circ} 35^{\prime} \mathrm{N}\right)$, Geochem. Geophys. Geosyst., 17, 3560-3579.

Einarsson, P., 1991. Earthquakes and present-day tectonism in Iceland, Tectonophysics, 189, 261-279.

Ekström, G., Nettles, M. \& Dziewonski, A.M., 2012. The global CMT project 2004-2010: centroid-moment tensors for 13,017 earthquakes, Phys. Earth planet. Inter., 200-201, 1-9.

Escartin, J., Cannat, M., Pouliquen, G., Rabain, A. \& Lin, J., 2001. Crustal thickness of V-shaped ridges south of the Azores: interaction of the MidAtlantic Ridge $\left(36^{\circ}-39^{\circ} \mathrm{N}\right)$ and the Azores hot spot, J. geophys. Res., 106(B10), $21719-21735$.

Fox, C.G., Dziak, R.P., Matsumoto, H. \& Schreiner, A.E., 1994. Potential for monitoring low-level seismicity on the Juan de Fuca Ridge using military hydrophone arrays, Mar. Technol. Soc. J., 27, 22-30.

Fox, C.G., Matsumoto, H. \& Tai-Kwan, A.L., 2001. Monitoring Pacific Ocean seismicity from an autonomous hydrophone array, J. geophys. Res., 106(B3), 4183-4206.

Frohlich, C., 1990. Note concerning non-double-couple source components from slip along surfaces of revolution, J. geophys. Res., 95(B5), 68616866.

Frohlich, C., 1994. Earthquakes with non-double-couple mechanisms, Science, 264, 804-809.

Frohlich, C., 1995. Characteristics of well-determined non-double-couple earthquakes in the Harvard CMT catalog, Phys. Earth planet. Inter., 91, 213-228.

Frohlich, C. \& Davis, S.D., 1990. Single-link cluster analysis as a method to evaluate spatial and temporal properties of earthquake catalogues, Geophys. J. Int., 100(1), 19-32.

Frohlich, C., Riedesel, A. \& Apperson, K.D., 1989. Note concerning possible mechanisms for non-double-couple earthquake sources, Geophys. Res. Lett., 16(6), 523-526.

Gac, S., Dyment, J., Tisseau, C. \& Goslin, J., 2003. Axial magnetic anomalies over slow-spreading ridge segments: insights from numerical 3-D thermal and physical modelling, Geophys. J. Int., 154(3), 618-632.

Gac, S., Tisseau, C., Dyment, J. \& Goslin, J., 2006. Modelling the thermal evolution of slow-spreading ridge segments and their off-axis geophysical signature, Geophys. J. Int., 164(18), 341-358.

Gale, A., Laubier, M., Escrig, S. \& Langmuir, C.H., 2013. Constraints on melting processes and plume-ridge interaction from comprehensive study 
of the FAMOUS and north FAMOUS segments, mid-atlantic ridge, Earth planet. Sci. Lett., 365, 209-220.

Gente, P. et al., 1995. Characteristics and evolution of the segmentation of the Mid-Atlantic Ridge between $20^{\circ} \mathrm{N}$ and $24^{\circ} \mathrm{N}$ during the last 10 million years, Earth planet. Sci. Lett., 129, 55-57.

Gente, P., Dyment, J., Maia, M. \& Goslin, J., 2003. Interaction between the Mid-Atlantic Ridge and the Azores hot spot during the last 85 Myr: emplacement and rifting of the hot spot-derived plateaus, Geochem. Geophys. Geosyst., 4(10), 1-23.

Goslin, J., Triatnord Scientific Party, 1999. Extent of Azores plume influence on the Mid-Atlantic Ridge north of the hotspot, Geology, 27(11), 991994

Goslin, J. et al., 2012. Spatiotemporal distribution of the seismicity along the Mid-Atlantic Ridge north of the Azores from hydroacoustic data: insights into seismogenic processes in a ridge-hot spot context. Geochem. Geophys. Geosyst., 13(2), Q02010.

Goud, M.R. \& Karson, J.A., 1985. Tectonics of short-offset, slow-slipping transform zones in the FAMOUS area, Mid-Atlantic ridge, Mar. Geophys. Res., 7, 489-514.

Gracia, E., Charlou, J.L., Radford-Knoery, J. \& Parson, L.M., 2000. Nontransform offsets along the Mid-Atlantic Ridge south of the Azores ( $38^{\circ}$ $\mathrm{N}-34^{\circ} \mathrm{N}$ ): ultramafic exposures and hosting of hydrothermal vents, Earth planet. Sci. Lett., 177, 89-103.

Gutenberg, B. \& Richter, C.F., 1944. Frequency of earthquakes in California, Bull. seism. Soc. Am., 34(4), 185-188.

Heirtzler, J.R. \& Van Andel, T.H., 1997. Project FAMOUS: its origin, programs and setting, Bull. geol. Soc. Am., 88, 481-487.

International Seismological Centre, On-line Bulletin, 2013. http://www.isc. ac.uk, Internatl. Seismol. Cent., Thatcham, UK.

Julian, B.R., Miller, A.D. \& Foulger, G.R., 1998. Non-double-couple earthquakes 1, Theory, Rev. Reviews of Geophyics, 36(4), 525-549.

Kawakatsu, H., 1991. Enigma of earthquakes at ridge-transform-fault plate boundaries distribution of non-double couple parameter of Harvard CMT solutions, Geophys. Res. Lett., 18(6), 1103-1106.

Klein, F.W., Wright, T. \& Nakata, J., 2006. Aftershock decay, productivity, and stress rates in Hawaii: indicators of temperature and stress from magma sources, J. geophys. Res., 111(B7), B07307.

Macdonald, K.C., 1977. Near-bottom magnetic anomalies, asymmetric spreading, oblique spreading, and tectonics of the Mid-Atlantic Ridge near lat. $37^{\circ} \mathrm{N}$, Bull. geol. Soc. Am., 88, 541-555.

Maia, M. \& Gente, P., 1998. Three-dimensional gravity and bathymetry analysis of the Mid-Atlantic Ridge between $20^{\circ} \mathrm{N}$ and $24^{\circ} \mathrm{N}$ : flow geometry and temporal evolution of the segmentation, J. geophys. Res., 103(B1), 951-974.

Maia, M., Goslin, J. \& Gente, P., 2007. Evolution of the accretion processes along the Mid-Atlantic Ridge north of the Azores since 5.5 Ma: an insight into the interactions between the ridge and the plume, Geochem. Geophys. Geosyst., 8(3), Q03013.

Magde, L.S., Barclay, A.H., Toomey, D.R., Detrick, R.S. \& Collins, J.A., 2000. Crustal magma plumbing within a segment of the Mid-Atlantic Ridge, $35^{\circ} \mathrm{N}$, Earth planet. Sci. Lett., 175, 55-67.

Nyffenegger, P. \& Frohlich, C., 2000. Aftershock occurrence rate decay properties for intermediate and deep earthquake sequences, Geophys. Res. Lett., 27(8), 1215-1218.

Pan, J. \& Dziewonski, M., 2005. Comparison of mid-oceanic earthquake epicentral differences of travel time, centroid locations, and those determined by autonomous underwater hydrophone arrays, J. geophys. Res., 110, B07302.

Parker, R.L., 1973. The rapid calculation of potential anomalies, J. geophys. Res., 31, 447-455.

Parson, L., Gracia, E., Coller, D., German, C. \& Needham, D., 2000. Secondorder segmentation: the relationship between volcanism and tectonism at the MAR, $38^{\circ} \mathrm{N}-35^{\circ} 40^{\prime} \mathrm{N}$, Earth planet. Sci. Lett., 178, 231-251.

Paulatto, M., Canales, J.P., Dunn, R.A. \& Sohn, R.A., 2015. Heterogeneous and asymmetric crustal accretion: new constraints from multi-beam bathymetry and potential field data from the Rainbow area of the MidAtlantic Ridge $\left(36^{\circ} 15^{\prime} \mathrm{N}\right)$, Geochem. Geophys. Geosyst., 16, 2994-3014.
Perrot, J., 2010. HYDROBS-MOMAR 2010 cruise, RV Le Suroit. Perrot, J., 2011. HYDROBS-MOMAR 2011 cruise, RV Le Suroît.

Ramberg, I.B., Gray, D.F. \& Raynolds, R. G_H, 1977. Tectonic Evolution of the FAMOUS Area of the Mid-Atlantic Ridge, Lat. $35^{\circ} 50^{\prime}$ to $37^{\circ} 20^{\prime} \mathrm{N}$, Bull. geol. Soc. Am. 88, 609-620.

Reid, I. \& Macdonald, K.C., 1973. Microearthquake study of the MidAtlantic Ridge near $37^{\circ} \mathrm{N}$ using sonobuoys, Nature, 246, 88-90.

Rubin, A.M., 1992. Dike-induced faulting and graben subsidence in volcanic rift zones, J. geophys. Res., 97, 1839-1858.

Rubin, A.M. \& Gillard, D., 1998. Dike-induced earthquakes: theoretical considerations, J. geophys. Res., 103, 10 017-10 030.

Shuler, A. \& Nettles, M., 2012. Earthquake source parameters for the 2010 western Gulf of Aden rifting episode, Geophys. J. Int., 190, 111-1122.

Shuler, A., Nettles, M. \& Ekström, G., 2013. Global observation of vertical-CLVD earthquakes at active volcanoes, J. geophys. Res., 118, $138-164$.

Simão, N., Escartín, J., Goslin, J., Haxel, J., Cannat, M \& Dziak, R., 2010. Regional seismicity of the Mid-Atlantic Ridge: observations from autonomous hydrophone arrays, Geophys. J. Int., 183(3), $1559-1578$.

Sinton, J.M. \& Detrick, R.S., 1992. Mid-ocean ridge magma chambers, J. geophys. Res., 97(B1), 197-216.

Smith, D.K. \& Cann, J.R., 1993. Building the crust at the Mid-Atlantic Ridge, Nature, 365, 707-715.

Smith, D.K., Tolstoy, M., Fox, C.G., Bohnenstiehl, D.R., Matsumoto, H. \& Fowler, M.J., 2002. Hydroacoustic monitoring of seismicity at the slowspreading Mid-Atlantic Ridge, Geophys. Res. Lett., 29(11), 13-1-13-4.

Teague, W.J., Carron, M.J. \& Hogan, P.J., 1990. A comparison between the Generalized Digital Environmental Model and levitus climatologies, Tech. Rep., DTIC Document.

Toda, S., Stein, R.S. \& Sagiya, T., 2002. Evidence from the AD $2000 \mathrm{Izu}$ islands earthquake swarm that stressing rate governs seismicity, Nature, 419, 58-61.

Thibaud, R., Gente, P. \& Maia, M., 1998. A systematic analysis of the Mid-Atlantic Ridge morphology and gravity between $15^{\circ} \mathrm{N}$ and $40^{\circ} \mathrm{N}$ : constraints of the thermal structure, J. geophys. Res., 103(B10), 24 223-24 243

Tolstoy, M., Bohnenstiehl, D.R., Edwards, M. \& Kurras, G., 2001. Seismic character of volcanic activity at the ultraslow-spreading Gakkel Ridge, Geology, 29, 1139-1142.

Tsang-Hin-Sun, E., Royer, J.-Y. \& Perrot, J., 2016. Seismicity and active accretion processes at the ultraslow-spreading Southwest and intermediatespreading Southeast Indian ridges from hydroacoustic data, Geophys. J. Int., 206(2), 1232-1245.

Utsu, T. \& Ogata, Y., 1997. Statistical analysis of seismicity, in IASPEI Software Library 6, pp. 13-94, eds Healy, J.H., Kelis-Borok, V.I. \& Lee, W.H.K., IASPEI and Seismological Society of America.

Utsu, T., Ogata, Y. \& Matsu'ura, R.S., 1995. The centenary of the Omori formula for a decay law of aftershock activity, J. Phys. Earth, 43, 1-33.

Wessel, P., Smith, W.H., Scharroo, R., Luis, J. \& Wobbe, F., 2013. Generic mapping tools: improved version released, EOS, Trans. Am. geophys. Un. 94, 409-410.

Wilcock, W.S.D. et al., 2016. Seismic constraints on caldera dynamics from the 2015 Axial Seamount eruption, Science, 354(6318), 1395-1398.

Yang, T., Shen, Y., van der Lee, S., Solomon, S.C. \& Hung, S.-H., 2006. Upper mantle structure beneath the Azores hotspot from finite-frequency seismic tomograph, Earth planet. Sci. Lett., 250, 11-26.

Goslin, J., Lourenço, N., Dziak, R. P., Bohnenstiehl, D. R., Haxel , J. \& Luis, J., 2005. Long-term seismicity of the Reykjanes Ridge (North Atlantic) recorded by a regional hydrophone array. Geophys. J. Int., 162(2), 516524

Knopoff, L. \& Randall, M. J., 1970. The Compensated Linear VectorDipole: A possible Mechanism for Deep Earthquakes, J. geophys. Res. 75(26), 4957-4963.

Fox, C.G. \& Dziak, R. P., 1998. Hydroacoustic detection of volcanic activity on the Gorda Ridge, February-March 1996, Deep-Sea Res. II, 45(12), $2513-2530$ 